\title{
General and Particular Approaches to Implementation of the European Convention on Human Rights
}

\author{
Approches générales et particulières à la mise en \\ ouvre de la Convention européenne des droits de l'homme
}

\author{
VLADIMÍRA PEJCHALOVÁ GRÜNWALDOVÁ
}

\begin{abstract}
This article deals with the implementation, at the national level, of European human rights protection standards as enshrined in the European Convention on Human Rights (ECHR) and interpreted by the European Court of Human Rights (ECtHR). It discusses the principles of interpretation of the ECHR by the ECtHR, the interaction and mutual dialogue between the ECtHR and national courts, and the approach of the latter to interpretation and application of the case law of the ECtHR. Using the concrete examples of France and the Czech Republic as case studies, it is shown to what extent and how European constitutional courts take into account and apply the letter of the Convention and its interpretation by the ECtHR.
\end{abstract}

\begin{abstract}
Résumé
Cet article traite de la mise en œuvre, au niveau national, des normes européennes de protection des droits de l'homme telles qu'énoncées dans la Convention européenne des droits de l'homme et interprétées par la Cour européenne des droits de l'homme (Cour). Il examine les principes d'interprétation de la Convention par la Cour, l'interaction et le dialogue mutuel entre la Cour et les juridictions nationales, ainsi que l'approche de ces dernières en matière d'interprétation et d'application de la jurisprudence de la Cour. À partir des exemples concrets de la France et de la République tchèque, il est illustré dans quelle mesure et comment les instances constitutionnelles européennes prennent en compte et appliquent la lettre de la Convention ainsi que son interprétation par la Cour.
\end{abstract}

Vladimíra Pejchalová Grünwaldová, Lecturer in Private International Law, Faculty of Law, University of West Bohemia, Pilsen, Czech Republic (vladimira.grunwaldova@orange.fr). The author is a former case lawyer at the European Court of Human Rights and Permanent Representative of the Parliament of the Czech Republic to the Parliamentary Assembly of the Council of Europe. 
Keywords: European Convention on Human Rights; European Court of Human Rights; human rights implementation; constitutional courts; France; the Czech Republic.
Mots-clés: Convention européenne des droits de l'homme, Cour européenne des droits de l'homme; mise en ouvre des droits de l'homme; cours constitutionnelles; France; République tchèque.

\section{INTRODUCTION}

$\mathrm{T}$ he states parties to the European Convention on Human Rights (ECHR) are obliged to secure for everyone within their jurisdiction the rights and freedoms defined in the convention and to provide an effective remedy before a national authority for anyone whose rights and freedoms have been violated. ${ }^{1}$ The European Court of Human Rights (ECtHR) authoritatively interprets the ECHR and acts as a safeguard for individuals whose rights and freedoms have not been secured at the national level. ${ }^{2}$ In pursuance of their delineated competences, what are the principles of interaction between the ECtHR and national courts? Can the ECtHR be ranked above national constitutional jurisdictions as a sort of European Constitutional Court? Effective implementation of the case law of the ECtHR

${ }^{1}$ Convention for the Protection of Human Rights and Fundamental Freedoms, 4 November 1950, 213 UNTS 221 (entered into force 3 September 1953), art 1 [ECHR]: "The High Contracting Parties shall secure to everyone within their jurisdiction the rights and freedoms defined in Section I of this Convention." It follows from art 1 that member states must answer for any infringement of the rights and freedoms protected by the ECHR committed against individuals placed under their "jurisdiction." The exercise of jurisdiction is a necessary condition for a contracting state to be able to be held responsible for acts or omissions imputable to it that give rise to an allegation of the infringement of rights and freedoms set forth in the convention (see e.g. Ilaşcu and Others v Moldova and Russia [GC], No 48787/99, [2004] VII ECHR 179 at para 311; Mozer v Republic of Moldova and Russia [GC], No $11138 / 10$, [2016] ECHR 213 at para 97). The concept of "jurisdiction" for the purposes of art 1 of the ECHR reflects the term's meaning in public international law (see e.g. Banković and Others v Belgium and Others (dec) [GC], No 52207/99, [2001] XII ECHR 333 at paras 59-61; Gentilhomme, Schaff-Benhadji and Zerouki v France, No 48205/99 (14 May 2002) at para 20; Assanidze v Georgia [GC], No 71503/o1, [2004] II ECHR 221 at para 137). From the standpoint of public international law, the words "within their jurisdiction" in art 1 of the ECHR must be understood to mean that a state's jurisdictional competence is primarily territorial (see e.g. Banković, ibid at para 59; Mozer, ibid at para 97).

${ }^{2}$ See e.g. A Stone Sweet \& H Keller, "The Reception of the ECHR in National Legal Orders" in H Keller \& A Stone Sweet, eds, A Europe of Rights: The Impact of the ECHR on National Legal Systems (Oxford: Oxford University Press, 2008) 10. The authors note that the European Court of Human Rights (ECtHR) is not only endowed with "exclusive" and "final" jurisdiction over "all matters concerning the interpretation and application of the Convention" but that it also has authority to ensure that states parties meet the obligation to secure to everyone within their jurisdiction the rights and freedoms guaranteed by the ECHR. Such authority of the ECtHR "is largely insulated" from the control of the states parties. 
requires that national law be interpreted in harmony with it. As we shall see, the way and extent to which national constitutional bodies take into account and apply the letter of the ECHR and its interpretation by the ECtHR varies depending on the status of the convention within the given national legal order and on the relevance of the ECtHR's interpretation of it in the practice of the relevant national constitutional jurisdiction. This will be demonstrated, first, by outlining the general context in which national constitutional jurisdictions and the ECtHR interact and, second, by reviewing the manner in which the French and the Czech constitutional jurisdictions approach the ECtHR's rulings and, in particular, the extent to which the respective constitutional bodies of each state strive for harmony with the ECtHR.

The structure of the article proceeds from an overview of the general principles and approaches underlying the interrelationship between the ECtHR and national courts and then leads into practical examples of this interrelationship. The objective is to first give an insight into the theoretical background of the interaction between the ECtHR and national courts before approaching the concrete national supreme courts' practice with respect to the ECHR and the case law of the ECtHR. The outline of general principles and approaches governing the interaction between the ECtHR and national courts aims at providing an understanding of the general theoretical framework within which these actors operate. Using the examples of two European jurisdictions - France and the Czech Republic - we then shall see how these principles of interaction are applied in practice. The two case studies will provide an understanding of the practical functioning of the mutual dialogue that is conducive to the attainment of greater effectiveness in the protection of fundamental rights and freedoms. We shall see that the different principles governing the dialogue between the ECtHR and national courts represent important tools of interpretation for the ECtHR in its decision-making. The way in which the ECtHR interprets the ECHR influences the jurisprudence of national courts, which in turn strive to interpret national law in harmony with the ECtHR. The examination of the status of the ECHR within the French and Czech legal orders, and the relevance of the ECHR and the case law of the ECtHR in the practice of the French and Czech supreme courts, will demonstrate the extent to which some of Europe's highest national courts implement the interpretative approaches of the ECtHR.

\section{ImPlementation of the ECHR by the ECtHR and National Courts: General Principles ANd Approaches}

\section{PRINCIPLES OF INTERACTION BETWEEN THE COURTS}

The interaction between the ECtHR and national courts is based on the principle of subsidiarity, meaning that states have the primary responsibility 
to secure fundamental rights and freedoms, subject to the supervisory jurisdiction of the ECtHR, in view of the fact that national authorities are, in principle, better placed than an international court to evaluate local needs and conditions. ${ }^{3}$ The ECHR system is subsidiary to the safeguarding of human rights at the national level and does not function as a "fourth instance" in dealing with human rights cases. ${ }^{4}$

The principle of subsidiarity is reflected in the criterion of the margin of appreciation that the ECtHR leaves to states in cases in which there is no broad European consensus. ${ }^{5}$ The jurisprudence of the ECtHR

${ }^{3}$ The ECtHR has consistently held that the scope of this margin varies according to the circumstances, the subject matter, and the background. A wide margin is usually allowed to states under the ECHR not only when it comes to general measures of economic or social strategy but also when it comes to delicate moral problems where there is no consent among the states parties. Because of their direct knowledge of their society and its needs, the national authorities are, in principle, better placed than the international judge to appreciate what is in the public interest on social or economic grounds, and the ECtHR generally respects the legislature's policy choice unless it is "manifestly without reasonable foundation." See e.g. James and Others v United Kingdom (1986) 98 ECHR (Ser A) 2 at para 46; National E Provincial Building Society, Leeds Permanent Building Society and Yorkshire Building Society v United Kingdom, [1997] VII ECHR 87 at para 80; Stec and Others v United Kingdom [GC], No 65731/o1, [2006] VI ECHR 131 at para 52; Tkachevy v Russia, No 35430/05 (14 February 2012 ) at para 36.

${ }^{4}$ See e.g. J Laffranque et al, "Subsidiarity: A Two-Sided Coin?" (Background Paper to Seminar to Mark the Official Opening of the Judicial Year 2015, 30 January 2015) at 4, online: <http://wwww.echr.coe.int/Documents/Seminar_background_paper_2015_ ENG.pdf> ; E Bjorge, Domestic Application of the ECHR: Courts as Faithful Trustees (Oxford: Oxford University Press, 2015) at 186. From the ECtHR's case law, see e.g. García Ruiz $v$ Spain [GC], No 30544/96, [1999] I ECHR 87 at para 28 [García Ruiz], in which the ECtHR held that "it is not its function to deal with errors of fact or law allegedly committed by a national court unless and in so far as they may have infringed rights and freedoms protected by the Convention." See also Anheuser-Busch Inc v Portugal [GC], No 73049/o1, [2007] I ECHR 39 at para 83, in which the ECtHR reiterated that "its jurisdiction to verify that domestic law has been correctly interpreted and applied is limited" and that "it is not its function to take the place of the national courts, its role being rather to ensure that the decisions of those courts are not flawed by arbitrariness or otherwise manifestly unreasonable."

${ }^{5}$ Such as, in regard to religious symbols in classrooms in Lautsi v Italy [GC], No 30814/o6 (18 March 2011) at para 68; see also e.g. Vo v France [GC], No 53924/oo, [2004] VIII ECHR 67 at para 82 [Vo]. The ECtHR held that "[i]t follows that the issue of when the right to life begins comes within the margin of appreciation which the Court generally considers that States should enjoy in this sphere, notwithstanding an evolutive interpretation of the ECHR, a 'living instrument which must be interpreted in the light of present-day conditions'. The reasons for that conclusion are, firstly, that the issue of such protection has not been resolved within the majority of the Contracting States themselves, in France in particular, where it is the subject of debate and, secondly, that there is no European consensus on the scientific and legal definition of the beginning of life." 
makes it clear that states enjoy a margin of appreciation in how they apply and implement the ECHR, depending on the circumstances of the case and the rights and freedoms engaged. The margin of appreciation goes hand in hand with supervision under the convention system. In this respect, the role of the ECtHR is to review whether decisions taken by national authorities are compatible with the ECHR. ${ }^{6}$ Explicit reference to the principle of subsidiarity and the doctrine of the margin of appreciation is contained in Protocol No. 15 to the ECHR, which has not yet come into force. ${ }^{7}$

The principles of subsidiarity and margin of appreciation are not the only important elements of the dialogue between the ECtHR and national jurisdictions or the only important tools of interpretation that the ECtHR has at its disposal. Equally important in the mutual dialogue is the concept of "European consensus," which refers to an implicit consent or a trend emerging in the legal systems of the member states of the Council of Europe, or some of them, to accept a particular solution as a common standard. ${ }^{8}$ This concept serves to restrict the margin of appreciation and to support synergies between the case law of the ECtHR and the practice of national courts. As will be discussed in greater detail later in this article, if the ECtHR finds that there is consensus on a particular issue in Europe, the margin of appreciation left to states is correspondingly reduced and, vice versa, a lack of relevant consensus among states could speak in favour

${ }^{6}$ See JG Merrills \& AH Robertson, Human Rights in Europe: A Study of the European Convention on Human Rights, $4_{\text {th }}$ ed (Manchester: Manchester University Press, 2001) at 223-27; D Rook, Property Law and Human Rights (London: Blackstone Press, 2001) at 32-33; G Gauksdóttir, The Right to Property and the European Convention on Human Rights: A Nordic Approach (Lund: Lund University Press, 2004) at 20-2 1; A Paulus, "Subsidiarity: Dialogue between the Court and National Courts" in Proceedings of the MultiRights Annual Conference on the Long-term Future of the European Court of Human Rights (Oslo, Norway: Council of Europe, $7-8$ April 2014) $55^{\text {at }} 5^{6-57}$ [MultiRights Proceedings].

7 Protocol No 15 Amending the Convention for the Protection of Human Rights and Fundamental Freedoms, 24 June 2013, CETS No 213 , online: <https://www.echr.coe.int/Documents/ Protocol_15_ENG.pdf> [Protocol No 15]. Art 1 of Protocol No 15 inserts a new recital to the preamble of the ECHR, as follows: "Affirming that the High Contracting Parties, in accordance with the principle of subsidiarity, have the primary responsibility to secure the rights and freedoms defined in this Convention and the Protocols thereto, and that in doing so they enjoy a margin of appreciation, subject to the supervisory jurisdiction of the European Court of Human Rights established by this Convention."

${ }^{8}$ Vallianatos and Others v Greece [GC], No 29381/o9 (7 November 2013) at para 91. See further K Dzehtsiarou, "Interaction between the European Court of Human Rights and Member States: European Consensus, Advisory Opinions and the Question of Legitimacy" in S Flogaitis \& J Fraser, eds, The European Court of Human Rights and Its Discontents: Turning Criticism into Strength (Cheltenham, UK: Edward Elgar, 2013) 122. 
of allowing a wider margin of appreciation than normally afforded. ${ }^{9}$ Thus, European consensus facilitates interaction between member states and the ECtHR and enhances the legitimacy of the latter's judgments.

A certain limitation on the margin of appreciation also flows from the review of proportionality conducted by the ECtHR, which "requires the Court to review the substantive, political decisions of national officials in the context of national law, thereby reinforcing the Court's own structural supremacy." 10 The principle of proportionality requires that a reasonable relationship of proportionality be struck between the means employed and the aim sought to be realized. ${ }^{11}$ In other words, a measure restricting fundamental rights and freedoms must be necessary in a democratic society and must be directed at achieving a legitimate aim. As the ECtHR has specified, not only must the measure be appropriate for achieving its aim, but it also must not be disproportionate thereto. ${ }^{12}$ The case law uses for this purpose a fair-balance test, which is expressed by the ECtHR as a requirement that a fair balance be struck between the collective interest and the interests of an individual. ${ }^{13}$ The legal scholarship denotes this as "proportionality in the narrower sense," 14 regarding rights as protected interests and the public interest as the common interest, which means that a suitable and necessary measure may not upset the fair balance or

${ }^{9}$ See e.g. Animal Defenders v United Kingdom [GC], No 48876/o8 (22 April 2013) at para 123. The ECtHR stated that there was no European consensus between contracting states on how to regulate paid political advertising in broadcasting. It underlined that while there might be a trend away from broad prohibitions, it remained clear that there was a substantial variety of means employed by the contracting states to regulate such advertising, reflecting the wealth of differences in historical development, cultural diversity, political thought, and, consequently, democratic vision of those states. According to the ECtHR, this lack of consensus also broadens the margin of appreciation to be accorded in regard to the restrictions on public interest expression. See also Hirst $v$ United Kingdom (no 2) [GC], No 74025/o1, [2005] IX ECHR 187 at para 81; SH and Others v Austria [GC], No 57813/oo, [2011] V ECHR 295 at para 94: "Where there is no consensus within the member States of the Council of Europe, either as to the relative importance of the interest at stake or as to the best means of protecting it, particularly where the case raises sensitive moral or ethical issues, the margin will be wider."

${ }^{10}$ A Stone Sweet, "On the Constitutionalisation of the Convention: The European Court of Human Rights as a Constitutional Court," Faculty Scholarship Series Paper 71 (2009).

${ }^{11}$ See e.g. Holy Monasteries v Greece (1994), 301A ECHR (Ser A) 49 at para 7o; BrossetTriboulet and Others $v$ France [GC], No 34078/o2 (29 March 2010) at para 86; Herrmann v Germany [GC], No 930o/o7 (26 June 2012) at para 74; Paulet v United Kingdom, No 62 19/o8 (13 May 2014) at para 64 .

${ }^{12}$ James, supra note 3 at para 5 o.

13 Sporrong and Lönnroth $v$ Sweden (1982), 52 ECHR (Ser A) 5 at para 69.

${ }^{14}$ See e.g. AR Coban, Protection of Property Rights within the European Convention on Human Rights (Aldershot: Ashgate, 2004) at 205; Bjorge, supra note 4 at 155 . 
destroy the essence of the protected right. ${ }^{15}$ Accordingly, the purpose of the fair-balance test is to assess whether a measure strikes a fair balance between the demands of the general interests of the community and the requirements of protection of the fundamental rights of an individual. ${ }^{16}$

The principle of proportionality, which is a central interpretative principle in international human rights law, has acquired the status of a general principle that applies to the whole of the $E C H R .{ }^{17}$ It has been developed by the ECtHR as a corrective and a restriction on the margin-of-appreciation doctrine, ${ }^{18}$ as national courts, when applying the ECHR in the domestic legal context, are obliged to apply the same proportionality test as the ECtHR in order to comply with the convention's requirements and to avoid the ECtHR finding a violation of the convention..$^{19}$ It may be argued that the wider the standard of proportionality, the narrower the margin of discretion allowed to national authorities.

The extent of the undertakings of states parties to the ECHR is also informed by the positive obligations imposed on them, whereby the ECtHR has extended the scope and impact of convention rights with a view to promoting the effective exercise of rights and freedoms guaranteed by the convention. The defining characteristic of positive obligations is that they require national authorities to take measures necessary to safeguard a right or to adopt reasonable and suitable measures to protect the rights of the individual. ${ }^{20}$ Hence, by imposing positive obligations, the ECtHR extends the requirements that national authorities are obliged to satisfy under the convention. A certain dimension of the dialogue also emerges from civil law cases between private parties, in which the ECtHR deals with the balancing of the rights of such parties. They may give rise to divergence between the ECtHR and the state as to the attainment of the reasonable balance of the conflicting interests at stake, as shown by

${ }^{15}$ J Christoffersen, "Straight Human Rights Talk: Why Proporionality Does (Not) Matter" in P Wahlgren, ed, Human Rights, Their Limitations and Proliferation, Scandinavian Studies in Law, vol 55 (Stockholm: Stockholm Institute for Scandinavian Law, 2010) 17.

${ }^{16}$ See e.g. Depalle v France [GC], No 34044/o2, [2010] III ECHR 233 at para 83; Bittó and Others $v$ Slovakia, No 30255/o9 (28 January 2014) at para 97.

${ }^{17}$ Christoffersen, supra note 15 .

${ }^{18}$ F Matscher, "Methods of Interpretation of the Convention" in R St J Macdonald, F Matscher \& H Petzold, eds, The European System for the Protection of Human Rights (Dordrecht: Martinus Nijhoff, 1993) 79 .

${ }^{19}$ Bjorge, supra note 4 at 157 .

${ }^{20} \mathrm{~J}-\mathrm{F}$ Akandji-Kombe, Positive Obligations under the European Convention on Human Rights: A Guide to the Implementation of the European Convention on Human Rights (Strasbourg: Council of Europe, 2007) at 7. In this respect, see, in particular, Dickson v United Kingdom [GC], No 44362/o4, [2007] V ECHR 99; Hämäläinen v Finland [GC], No 37359/o9, [2014] IV ECHR 369. 
a recent example concerning the issue of retroactive effects of a statute implementing a judgment of the ECtHR.

The case of Fabris $v$ France pertained to a difference in the treatment of legitimate and illegitimate children for succession purposes. ${ }^{21}$ The applicant claimed that, on account of his status as a child "born of adultery," he had been refused the right to request an abatement of the inter vivos division signed by his mother. Based on the facts, the Court of Cassation dismissed the applicant's appeal in 2007 , reasoning that the distribution of the estate between the two legitimate children had been done before a 2001 law came into force, which was why the provisions of that law relating to new inheritance rights of illegitimate children were not applicable to Mr. Fabris. ${ }^{22}$ The Loi no. 200 I-I 135 relative aux droits du conjoint survivant et des enfants adultérins et modernisant diverses dispositions de droit successoral (2oo I Law) implemented the Mazurek v France judgment, which declared that inequality of inheritance rights on grounds of birth was incompatible with the ECHR ${ }^{23}$ France accordingly amended the rules of inheritance by repealing all of the discriminatory provisions relating to children "born of adultery." The 200 I Law stipulated that the provisions of that law were not applicable to inheritance arrangements that had already given rise to distribution before the law came into force. ${ }^{24}$ According to the French government, it was not possible to undermine rights acquired by third parties - in this case by the other heirs - and that this justified restricting the retroactive

${ }^{21}$ Fabris v France [GC], No 16574/o8, [2013] I ECHR 425 [Fabris].

${ }^{22}$ Loi no $200 \mathrm{I}-\mathrm{I} 135$ du 3 décembre $200 \mathrm{I}$ relative aux droits du conjoint survivant et des enfants adultérins et modernisant diverses dispositions de droit successoral [20o I Law]. This law eliminated the restrictions on inheritance rights of children "born of adultery" and conferred equal status for inheritance purposes on all children, be they legitimate, born to unmarried parents or "born of adultery."

${ }^{23}$ Mazurek v France, No 34406/97, [200o] II ECHR 23 [Mazurek].

${ }^{24}$ At the material time, art 25 (II) of the 200 I Law, supra note 22, read as follows:

La présente loi sera applicable aux successions ouvertes à compter de la date prévue au I, sous les exceptions suivantes:

1. L'article $763 \mathrm{du}$ code civil dans sa rédaction issue de l'article 4 et l'article 15 de la présente loi sera applicable aux successions ouvertes à compter de la publication de celle-ci au Journal officiel de la République française.

2. Sous réserve des accords amiables déjà intervenus et des décisions judiciaires irrévocables, seront applicables aux successions ouvertes à la date de publication de la présente loi au Journal officiel de la République française et n'ayant pas donné lieu à partage avant cette date:

- les dispositions relatives aux nouveaux droits successoraux des enfants naturels dont le père ou la mère était, au temps de la conception, engagé dans les liens du mariage ;

- les dispositions du second alinéa de l'article $15^{27}$ du code civil dans sa rédaction issue de l'article 17.

The relevant provision of Article 25 (II. 2.) of the 2001 Law read that: 
effect of the 20o I Law to those successions that were already open on the date of its publication and had not given rise to division by that date. ${ }^{25}$ However, the ECtHR held that the applicant had been deprived of a reserved portion of the estate and that he was placed in a different situation than that of the legitimate children regarding the inheritance of their mother's estate, and that the legitimate aim of protecting the inheritance rights of the applicant's half-brother and half-sister was not sufficiently weighty to override the claim by the applicant to a share in his mother's estate. ${ }^{26}$ The ECtHR stated that there was no objective and reasonable justification for the difference in treatment regarding the applicant. ${ }^{27}$

The present Law shall apply to successions that are already open from [1 July 2002], subject to the following exceptions:

2. Subject to any prior agreement between the parties or final court decision, the following shall apply to successions already open on the date of publication of the present Law in the Official Gazette of the French Republic and not having given rise to division prior to that date:

- the provisions relating to the new inheritance rights of children born outside marriage whose father or mother was, at the time of conception, bound by marriage to another person.

The entry into force of the 2001 Law was deferred until 1 July 2002. But regarding the repeal of the provisions of the Civil Code concerning the rights of children "born of adultery," the law came into force immediately on the date of publication of the law in the Official Gazette on 4 December 2001. Thus, in so far as it concerns the rights of children "born of adultery," the 200 I Law was applicable to all successions open on 4 December 2001 on the condition that there had been no division prior to that date.

${ }^{25}$ Fabris, supra note 21 at para 41 (extracts): "It was to those rights acquired by the other heirs that the legislature in 2001 - having, moreover, fully satisfied the general obligations incumbent on it to execute the Mazurek judgment - had to have regard when bringing the Law into force. Application of the new Law to pre-existing situations necessarily had to abide by the principles of legal certainty and foreseeability of the law established by the case-law of the Court. Section 25 of the 200 I Law thus excluded application of the new rights to successions already open on the date of its publication that had given rise to division before that date."

${ }^{26}$ Ibid at para 61 (extracts): "It is not in dispute in the present case that the applicant was deprived of a reserved portion and definitively placed in a different situation from that of the legitimate children regarding inheritance of their mother's estate. He was precluded from obtaining an abatement of the inter vivos division from which he had been excluded and a reserved portion on grounds of his status as a child "born of adultery." And: "Accordingly, in the light of the foregoing, the Court considers that the legitimate aim of protecting the inheritance rights of the applicant's half-brother and half-sister was not sufficiently weighty to override the claim by the applicant to a share in his mother's estate" (at para 70 (extracts)).

27 Ibid at para 73 (extracts): "In the light of all the aforementioned considerations, the Court concludes that there was no reasonable relationship of proportionality between the means employed and the legitimate aim pursued. There was therefore no objective and reasonable justification for the difference in treatment regarding the applicant. Accordingly, there has been a violation of Article 14 of the ECHR taken in conjunction with Article 1 of Protocol No 1." 
This judgment raises concerns as the ECtHR required France to apply its judgment on inheritance law retroactively. This case challenges the state's margin of appreciation and involves a clash between the general principle of legal certainty in legal relations and the ECtHR's interpretation of the margin of appreciation of states in choosing the means by which to execute the ECtHR's judgments. Although the ECtHR admitted that it is not, in principle, required to settle disputes of a purely private nature, it considered that the factual, non-retroactive interpretation of the law by the national court "appears unreasonable, arbitrary and blatantly inconsistent with the prohibition of discrimination." ${ }^{28}$ It basically held that the non-retroactive interpretation of national law by the national courts was in conflict with the ECHR.

By striving to prevent further violations similar to those found in the Mazurek judgment, did the ECtHR not catalyze another interference with the rights of the other private party who took up inheritance in good faith? It is evident that the ECtHR clearly favoured the seriousness of the discrimination against illegitimate children over the retroactive effects of the legislation and, thus, over legal certainty in concrete inheritance relationships. But is it not positive discrimination to find that the inheritance rights of the applicant bear more weight than the bona fide rights of legitimate children by unyieldingly insisting on the retroactive application of the $200 \mathrm{I}$ Law? These considerations lead one to contemplate whether the ECtHR should not be less rigorous in exercising its supervision over decisions of national authorities that seek to balance the interests of private parties. Perhaps the ECtHR's supervision should rather be stricter in "vertical" cases, involving disputes between the state and private persons, for such disputes always entail a certain imbalance of power to the benefit of the state that bears obligations to protect the rights of private persons.

\section{PRINCIPLES OF INTERPRETATION OF THE CONVENTION}

The ECtHR has long held that it must interpret and apply the ECHR in a manner that renders its rights practical and effective, not theoretical and illusory, and that the convention must also be read as a whole and interpreted in such a way as to promote internal consistency and harmony

${ }^{28}$ In ibid at para 6o, the ECtHR stated that "[ $\left.\mathrm{t}\right]$ he Court is not in principle required to settle disputes of a purely private nature. That being said, in exercising the European supervision incumbent on it, it cannot remain passive where a national court's interpretation of a legal act, be it a testamentary disposition, a private contract, a public document, a statutory provision or an administrative practice appears unreasonable, arbitrary or blatantly inconsistent with the prohibition of discrimination established by Article 14 and more broadly with the principles underlying the Convention." 
between its various provisions. ${ }^{29}$ Moreover, referring to the "living" nature of the ECHR, the ECtHR has reiterated that, with regard to changing conditions in the contracting states, it must interpret the convention in light of "present-day conditions" and respond to any emerging consensus as to the standards to be achieved. ${ }^{30}$ In view of this, it seems that today the ECtHR's jurisprudence has a tendency to enlarge and diffuse into many new areas of law that have little to do with fundamental rights and, thus, to overstep the role that was originally ascribed to it in the ECHR system. It seems that the object and purpose of the convention and the role of the ECtHR, which were accurately described by the British Judge Sir Gerald Fitzmaurice in his dissenting opinion in the Marckx case, have expanded over time. ${ }^{31}$ This is due to the ECtHR's "dynamic" interpretation of the ECHR as a "living instrument" that should be interpreted as being applicable to new spheres of law, such as social security, whereby the ECtHR, besides declaring its intent to maintain the effectiveness of the convention, has assumed the power to adjudicate on issues surpassing the sphere of fundamental rights.

That the scope of the ECtHR's adjudicative function has increased to new areas can be illustrated, for example, by the judgment in Stec $v$ United Kingdom, in which the ECtHR interpreted the right to the peaceful enjoyment of possessions as encompassing state-financed and non-contributory welfare benefits. ${ }^{32}$ By virtue of this judgment, social support became "property" within the meaning of Article 1 of Protocol No. 1 to the ECHR, ${ }^{33}$

29 Stec and Others $v$ United Kingdom (dec) [GC], No 65731/o1, [2005] X ECHR 321 at paras 47-48 [Stec and Others]; Demir and Baykara v Turkey [GC], No 34503/97 (12 November 2008) at paras 66-67.

${ }^{30}$ See e.g. Weller v Hungary, No 44399/05 (31 March 2009) at para 28; Stec and Others, supra note 29 at paras 63-64; or, mutatis mutandis, Stafford $v$ United Kingdom [GC], No 46295/99, [2002] IV ECHR 115 at para 68.

${ }^{31}$ Marckx v Belgium, No 6833/74, [1979] 31 ECHR (Ser A) 2 at para 7, Dissenting Opinion of Judge Sir Gerald Fitzmaurice [Marckx]: "[T] he main, if not indeed the sole object and intended sphere of application of Article 8, was that of what I will call the 'domiciliary protection' of the individual. He and his family were no longer to be subjected to ... the whole gamut of fascist and communist inquisitorial practices such as had scarcely been known, at least in Western Europe, since the eras of religious intolerance and oppression, until (ideology replacing religion) they became prevalent again in many countries between the two world wars and subsequently. Such, and not the internal, domestic regulation of family relationships, was the object of Article 8, and it was for the avoidance of these horrors, tyrannies and vexations that "private and family life ... home and ... correspondence' were to be respected, and the individual endowed with a right to enjoy that respect - not for the regulation of the civil status of babies."

32 Stec and Others, supra note 29.

33 Protocol to the Convention for the Protection of Human Rights and Fundamental Freedoms, as amended by Protocol No I I, 20 March 1952, Eur TS No 9, art 1, online: <https://rm.coe. int/CoERMPublicCommonSearchServices/DisplayDCTMContent?documentId= ogoooo168006377c $>$. 
which may have had a negative impact on the potential national welfare reforms pursued by the Council of Europe member states with a view to cutting welfare benefits. ${ }^{34}$

The ECtHR considers evolutive interpretation necessary for maintaining the effectiveness of the ECHR. The former president of the ECtHR, Luzius Wildhaber, has noted that evolutive interpretation is fundamental to the effectiveness of the convention and the authority of the ECtHR, which must, in his opinion, seek to take change into account to be able to strike a balance between development and stability of the European standard of protection of human rights. In his opinion, this balance is conducive to the maintenance of the practical and effective nature of rights and to the implementation of the ECtHR's judgments on the national level. ${ }^{35}$ For this purpose, the ECtHR has taken account of norms of national and international law. ${ }^{36}$ It refers to general international law, international treaties, ${ }^{37}$ general principles of law recognized by civilized nations,${ }^{38}$ the principles

${ }^{34}$ See in particular the judgment of the Supreme Court of the United Kindgom, $S G$ E Ors, $R$ (on the Application of) $v$ Secretary of State for Work and Pensions, [2015] UKSC 16 (18 March 2015), online: <https://www.supremecourt.uk/decided-cases/docs/UKSC_2014_Oo79_ Judgment.pdf $>$, pertaining to the introducion of the benefit cap in the Welfare Reform Act 2OI 2. In the reasons for the judgment, it is mentioned, among other things, that the test in the case of Stec and Others, supra note 29, involved "high level social/economic policy" (at para 135).

${ }^{35}$ L Wildhaber, "European Court of Human Rights" (2002) 4o Can YB Intl L 310.

${ }^{36}$ See Soering v United Kingdom (1989), 161 ECHR (Ser A) 14 at para 102 [Soering]; Vo, supra note 5 at para 82; Mamatkulov and Askarov v Turkey [GC], No 46827/99, [2005] I ECHR 293 at para 121.

${ }^{37}$ E.g., the ECtHR has interpreted art 8 of the ECHR in light of the Convention on the Rights of the Child, 20 November 1989, 1577 UNTS 3 (entered into force 2 September 1990) and the European Convention on the Adoption of Children, 24 April 1967,634 UNTS 256, CETS No 202 (entered into force 26 April 1968). See in this respect Pini and Others $v$ Romania, No 78028/o1, [2004] V ECHR 297 at paras 139, 144; Emonet and Others v Switzerland, No 39051/o3 (13 December 2007) at paras 65-66. In Siliadin v France, No 73316/o1, [2005] VII ECHR 333 at paras $85^{-87}$, a reference was made to international treaties other than the ECHR. The ECtHR, in order to establish the state's positive obligation concerning "the prohibition on domestic slavery," took into account the provisions of universal international conventions (ILO Convention No 29 Concerning Forced or Compulsory Labour, 28 June 1930, 39 UNTS 55 (entered into force 1 May 1932); the Supplementary Convention on the Abolition of Slavery, the Slave Trade, and Institutions and Practices Similar to Slavery, 7 September 1956, 266 UNTS 3 (entered into force 30 April 1957); Convention on the Rights of the Child, ibid).

38 The ECtHR indicated so in Golder v United Kingdom (1975), 18 ECHR (Ser A) 1 at para 29 [Golder]. The Legal Committee of the Consultative Assembly of the Council of Europe foresaw in August 1950 that "the Commission and the Court [would] necessarily [have to] apply such principles" in the execution of their duties and thus considered it to be "unnecessary" to insert a specific clause to this effect in the ECHR. Documents of the Consultative Assembly, Working Papers of the $195^{\circ}$ Session, vol 3, no 93 (1950) at 982, para 5 . 
laid down by texts of universal scope,$^{39}$ jus cogens,${ }^{40}$ and Council of Europe instruments. ${ }^{41}$ To determine the meaning of the terms and phrases used in the ECHR, the ECtHR is guided mainly by the rules of interpretation provided for in Articles 31-33 of the Vienna Convention on the Law of Treaties (VCLT).$^{42}$ In accordance with the VCLT, the ECtHR is required to ascertain the ordinary meaning to be given to the words in their context and in the light of the object and purpose of the provision from which they are drawn. It may also have recourse to supplementary means of interpretation, either to confirm a meaning determined in accordance with the above steps or to coin a meaning when the former would otherwise be ambiguous, obscure, or manifestly absurd or unreasonable. ${ }^{43}$

It can be claimed that the rudimentary nature of the text of the ECHR requires that the ECtHR use evolutive interpretation, which, however, must not exceed the limits of the convention. But it can be observed that the most important jurisprudence of the ECtHR was delivered during the first three decades of its existence and has been constantly and frequently applied to present-day cases brought before the ECtHR. Even so, in view of changing social and economic circumstances, it is sometimes impossible to apply case law that is forty years old. A pregnant example is the evolving forms of property and economic relations. The nature of the text of the ECHR does not contribute much to understanding these evolving aspects of daily life and requires that the ECtHR use evolutive interpretation, and it is just this nature of the convention that allows such interpretation.

Evolutive interpretation provides the ECtHR with the flexibility necessary in the changing legal, social, and economic environment of Europe. Nonetheless, there are also critics of it who argue, for example, that it contradicts the consistency of the case law or the principle of legal certainty

${ }^{39}$ Soering, supra note 36 at para 102. The ECtHR took into account these principles in developing its case law concerning art 3 of the ECHR with respect to extradition to third countries.

${ }^{40}$ Al-Adsani v United Kingdom [GC], No 35763/97, [2001] XI ECHR 79 at para 55.

${ }^{41}$ In particular, recommendations and resolutions of the Committee of Ministers and the Parliamentary Assembly. See, among other authorities, Öneryıldız v Turkey [GC], No 48939/99, [2004] XII ECHR 79 at paras 59, 71, 9o, 93. The ECtHR has also made reference to norms emanating from other Council of Europe organs, even though those organs have no function of representing states parties to the ECHR, whether as supervisory mechanisms or expert bodies.

${ }^{42}$ See e.g. Golder, supra note 38 at para 29; Johnston and Others $v$ Ireland (1986), 112 ECHR (Ser A) 17 at paras 51 ff; Lithgow and Others $v$ United Kingdom (1986), 102 ECHR 8 at paras 1 14, 1 17; Witold Litwa v Poland, No 26629/95, [2000] III ECHR 289 at paras 57-59.

${ }^{43}$ See Saadi v United Kingdom [GC], No $13229 / 03$, [2008] I ECHR 31 at para 62. 
and predictability. ${ }^{44}$ There is some truth to this argument. It is commonplace that evolutive interpretation is necessary to secure the effectiveness of the system of European human rights protection. On the other hand, its use entails changes in the case law and, thus, disturbs the predictability of the ECtHR's judgments, especially when the ECtHR adjudicates in new areas of law that have little to do with fundamental rights. It has an impact on national legal orders of the Council of Europe member states, as the national authorities must take the case law into consideration, overreaching the ECHR's original "mission" of preventing the recurrence of wars and tyranny. It is beyond doubt that evolutive interpretation improves the effectiveness of human rights protection at the expense of the predictability of the case law. It is therefore necessary to seek a balance, which the ECtHR strives for by having resort to the European consensus doctrine to mitigate the "surprise" effect of evolutive interpretation. ${ }^{45}$

European consensus may constitute a relevant consideration for the ECtHR when interpreting the provisions of the ECHR in specific cases. The ECtHR has applied it in a number of cases. In regard to property, the case of Mazurek $v$ France is illustrative. ${ }^{46}$ In this case, Mazurek complained of an infringement of his right to respect for his family life, within the meaning of Article 8 of the ECHR, and of discrimination on account of his birth, within the meaning of Article 14, as well as of an infringement of his right to the peaceful enjoyment of his possessions under Article 1 of Protocol No 1 to the convention. The ECtHR stated that the institution of the family was not rigidly codified, whether historically, sociologically, or legally. With regard to the situation in the other member states of the Council of Europe, it noted that there was a clear trend towards the abolition of discrimination in relation to adulterine children. It could not disregard such developments in its interpretation, which was necessarily evolutive, of the relevant provisions of the ECHR, and it found a violation of the right to peaceful enjoyment of property in conjunction with Article 14 of the convention.

The use of European consensus in the legal reasoning of the ECtHR places restrictions not only on the ECtHR's evolutive interpretation but also, as observed earlier, on the margin of appreciation given to states. Some authors consider it to be a mediator between dynamic interpretation

${ }^{44}$ H Gribnau, "Legitimacy of the Judiciary" in E Hondius \& C Joustra, eds, Netherlands Reports to the Sixteenth International Congress of Comparative Law (Antwerpen: Intersentia, 2002) 25, online: $<$ https://ssrn.com/abstract $=2877985>$.

${ }^{45} \mathrm{~K}$ Dzehtsiarou, "European Consensus and the Evolutive Interpretation of the European Convention on Human Rights" (2011) 12:10 German Law Journal 1745.

${ }^{46}$ Mazurek, supra note 23 . 
and the margin of appreciation. ${ }^{47}$ The ECtHR itself has admitted that, being made up of a set of rules and principles that are accepted by the vast majority of states, the common international or domestic law standards of European states reflect a reality that it cannot disregard when it is called upon to clarify the scope of a ECHR provision that more conventional means of interpretation have not enabled it to establish with a sufficient degree of certainty. ${ }^{48}$

\section{TOWARDS HARMONY WITH THE ECTHR}

The influence of the ECtHR on national courts takes place primarily by way of the latter's interpretation and application of the ECtHR's case law. National courts strive to interpret national law in harmony with the ECtHR. They apply the ECtHR's case law, ${ }^{49}$ as they generally try to avoid possible conflicts ${ }^{50}$ and desire to reduce exposure to adverse judgments. ${ }^{51}$ In this regard, the former president of the ECtHR, Judge Dean Spielmann, observed that the level of jurisprudential dialogue seems to be constantly improving and that national courts seem to have been adopting more and more frequently the legal argumentation of the ECtHR in order to rationalize their own decisions. ${ }^{52}$

47 A Morawa, "The 'Common European Approach', 'International Trends', and the Evolution of Human Rights Law: A Comment on Goodwin and I v. the United Kingdom" (2002) 3:8 German Law Journal 5, online: <https://static 1.squarespace.com/static/ $5_{633 \text { oad3e }}$ bo 733 dccoc8495/t/56b97ed6ab48de38834ad6c4/1454997206498/GLJ_ Vol_03_No_08_Morawa.pdf $>$.

${ }^{48}$ See Sigurður A Sigurjónsson v Iceland, No 16130/90 (30 June 1993) at para 35; Sørensen and Rasmussen v Denmark [GC], No 52562/99, [2006] I ECHR 1 at paras $72-75$. In finding that the right to organize had a negative aspect that excluded closed-shop agreements, the ECtHR considered, largely on the basis of the European Social Charter and the case law of its supervisory organs, together with other European or universal instruments, that there was a growing measure of agreement on the subject at international level.

${ }^{49}$ E.g., the German Constitutional Court in its recent case law established that the judgments of the ECtHR serve to orientate and guide ("Orientierungs- und Leitfunktion") national courts in their interpretation and application of the ECHR. See Preventive Detention II, 4 May 2011, 2 BvR 2365/o9, BVerfGE 128,326 at $368 \mathrm{ff}$.

${ }^{50}$ C Lageot, "France" in J Gerards \& J Fleuren, eds, Implementation of the European Convention on Human Rights and of the Judgments of the ECtHR in National Case-law: A Comparative Analysis (Cambridge: Intersentia, 2014) 145 at 165 .

${ }^{51}$ E Lambert-Abdelgawad \& A Weber, "The Reception Process in France and Germany" in Keller \& Stone Sweet, supra note 2, 107 at 128.

${ }^{52}$ In his speech at the MultiRights Annual Conference on the Long-term Future of the European Court of Human Rights, the president of the ECtHR asserted: "On voit de plus en plus fréquemment les juridictions internes s'appuyer sur la Convention européenne des droits se l'homme telle qu'elle est appliquée à Strasbourg, mais, surtout, s'approprier les raisonnements juridiques de notre cour pour motiver leurs propres décisions." Dean Spielmann, "The Successes of and Challenges for the European Court, Seen from the Inside / Les succès et les défis posés à la Cour européenne, perçus de l'intérieur" in MultiRights Proceedings, supra note 6, $4^{2}$ at $4^{6-47}$. 
On becoming states parties to the ECHR, the Council of Europe member states took upon themselves a commitment to take into account not only individual judgments that are binding on each of them but also the findings of the ECtHR in general. ${ }^{53}$ As Constance Grewe appositely points out, the ECtHR's function is "not only to determine specific issues and decide specific cases, it is also to state what the law is, to deliver an authentic interpretation of the Convention, to create a European standard of rights protection." 54 The case law of the ECtHR generally serves to elucidate, safeguard, and develop the rules instituted by the ECHR, thereby contributing to the observance by states of the engagements undertaken by them as contracting parties. ${ }^{55}$ The case law of the ECtHR, thus, has the effect of res interpretata that should be taken into account by national authorities in their application and interpretation of the ECtHR's case law with a view to harmonizing human rights protection norms across the continent and promoting the rule of law for maintaining and furthering the achieved common standard in the protection of human rights.

This res interpretata effect of the judgments of the ECtHR will be strengthened by Protocol No 16 to the ECHR, which should contribute to the enhancement of the interaction between the ECtHR and national jurisdictions. ${ }^{56}$ On the entry into force of this protocol, the highest national

${ }^{53}$ Pursuant to art 46 , para 1, of the ECHR, "[t] he High Contracting Parties undertake to abide by the final judgment of the Court in any case to which they are parties." See E Lambert-Abdelgawad, "The Execution of Judgments of the European Court of Human Rights," Human Rights Files No 19 (Strasbourg: Council of Europe Publishing, 2002) at 7, online: <https://www.echr.coe.int/LibraryDocs/DG2/HRFILES/DG2-ENHRFILES-19(2002).pdf>. The author submits that "judgments of the European Court have binding authority for the parties" and that "although judgments of the European Court are not binding erga omnes, their binding authority extends beyond the confines of the particular case." In this respect, see Marckx, supra note 31 at para $5^{8:}$ "Admittedly, it is inevitable that the Court's decision will have effects extending beyond the confines of this particular case, especially since the violations found stem directly from the contested provisions and not from individual measures of implementation."

${ }^{54}$ Constance Grewe presented her observations in the framework of a seminar on the topic "Ten Years of the 'New' European Court of Human Rights 1998-2008: Situation and Outlook" (Proceedings of the Seminar, European Court of Human Rights, 13 October 2008) at 42 .

${ }_{55}$ See e.g. Ireland $v$ United Kingdom (1978), 25 ECHR (Ser A) 1 at para 154; Guzzardi v Italy (1980), 39 ECHR (Ser A) 5 at para 86; Karner v Austria, No 40016/98, [2003] IX ECHR 199 at para 26.

${ }_{56}$ Protocol No I 6 to the Convention for the Protection of Human Rights and Fundamental Freedoms, 2 October 2013, CETS No 214, online: <https://www.echr.coe.int/Documents/Protocol_ 16_ENG.pdf $>$ [Protocol No I 6 ]. The Group of Wise Persons, set up under the Action Plan adopted at the third Summit of Heads of State and Government of the Member States 
courts and tribunals will have the possibility of requesting the ECtHR to give non-binding advisory opinions on questions of principle relating to the interpretation or application of the rights and freedoms defined in the ECHR or the protocols thereto ${ }^{57}$ Protocol No 16 , thus, envisages a new form of dialogue - an institutional dialogue - between the highest national courts and the Strasbourg court in the context of cases pending before these national courts, which will complement the jurisprudential interaction between the courts. Protocol No 16 may also be conducive to the strengthening of the subsidiary role of the Strasbourg court, as the advisory opinions may have the effect that cases pertaining to alleged violations of human rights will be settled more frequently at the national level.$^{58}$ It may also lead to a more consistent implementation of the ECHR across Europe, considering that the ECtHR is the final arbiter of the interpretation and application of the convention in all member states of the Council of Europe. These considerations lead to the following question. Can the ECtHR be perceived as the Constitutional Court of Europe?

\section{THE EUROPEAN COURT OF HUMAN RIGHTS: THE CONSTITUTIONAL COURT OF EUROPE?}

An answer in the affirmative may be tempting in view of the ECtHR's standard-setting role in the area of human rights protection. The ECtHR has reiterated on many occasions that its mission is also to raise the general standards of protection of human rights and extend human rights jurisprudence throughout the community of states under the

of the Council of Europe (Warsaw, 16-17 May 2005), stated that "it would be useful to introduce a system under which the national courts could apply to the Court for advisory opinions on legal questions relating to interpretation of the Convention and the protocols thereto, in order to foster dialogue between courts and enhance the Court's 'constitutional' role." See Report of the Group of Wise Persons to the Committee of Ministers, $\operatorname{Doc} \operatorname{CM}(2006) 203$ ( 15 November 2006) at para 135.

${ }^{57}$ Pursuant to art 1 of Protocol No I6, supra note $5^{6}$ :

1. Highest courts and tribunals of a High Contracting Party, as specified in accordance with Article 10, may request the Court to give advisory opinions on questions of principle relating to the interpretation or application of the rights and freedoms defined in the Convention or the protocols thereto.

2. The requesting court or tribunal may seek an advisory opinion only in the context of a case pending before it.

3. The requesting court or tribunal shall give reasons for its request and shall provide the relevant legal and factual background of the pending case.

${ }^{58}$ Judge Spielmann expressed his opinion that advisory opinions will even have an importance comparable to that of the ECtHR's landmark judgments. See Spielmann, supra note $5^{2}$ at 47 . 
ECHR by determining issues on public policy grounds in the common interest. ${ }^{59}$ But, although the ECtHR performs a standard-setting role in the area of human rights protection, this should not justify it being considered as the European constitutional court in the true sense of those words. Rather, its role consists in serving as a reference point in the area of human rights protection that comprises both the static aspect, represented by model norms of standard protection that are shared with the national legal systems, and the dynamic aspect, consisting of interactions with national courts within the limits of its competence given by the ECHR and its protocols. ${ }^{60}$

There are some who believe that the ECtHR has attained a constitutional character and that it has thus become a European constitutional court. ${ }^{61}$ The main arguments put forward by proponents of this idea are that the $E C H R$ has been incorporated into the national law of most member states of the Council of Europe, that the case law of the ECtHR is often referred to

${ }^{59}$ See e.g. Capital Bank AD v Bulgaria, No 49429/99, [2005] XII ECHR 37 at paras 78-79; Rantsev v Cyprus and Russia, No 25965/04 (7 January 2010) at para 197; Konstantin Markin v Russia [GC], No 30078/o6, [2012] III ECHR 77 at para 89. In the latter case, the ECtHR considered that the subject matter of the application - the difference in treatment under Russian law between servicemen and servicewomen in regard to the entitlement to parental leave - involved an important question of general interest not only for Russia but also for other states parties to the ECHR. It thus considered that further examination of the application would contribute to elucidating, safeguarding, and developing the standards of protection under the ECHR.

${ }^{60}$ First of all, the ECtHR operates within the sphere of international law. As A Stone Sweet and $\mathrm{H}$ Keller appositely submit, the ECtHR does not possess, unlike national constitutional or supreme courts, the "authority to invalidate national legal norms judged to be incompatible with the Convention" and it "does not preside over a hierarchically constituted judicial system in which it exercises appellate review, or cassation powers, when it comes to decisions of national courts." They underline that the ECtHR "performs its most important governance functions through the building of a precedent-based caselaw." Stone Sweet \& Keller, supra note 2 at 13-14. Regarding the static aspect of the role of the ECtHR, it can be underpinned by a claim put forward by E Bjorge that the national courts see the ECHR as interpreted by the ECtHR as a "floor" or a minimum standard that they shall observe. He further submits that not falling behind the standards of the ECtHR in the application of the convention involves a dialogue between the ECtHR and national courts and other factors, such as the doctrine of autonomous concepts, the evolutionary interpretation of treaties, the international margin of appreciation, and the strictures of proportionality. This argument evidently relates to the dynamic relationship between the ECtHR and the national courts. Bjorge, supra note 4 at 12 .

${ }^{61}$ S Greer \& L Wildhaber, "Revisiting the Debate about 'Constitutionalising' the European Court of Human Rights" (2012) 12:4 Human Rights L Rev 655 at $667-68$. The authors submit four constitutional characteristics of the ECtHR and the ECHR system: (1) the ECHR is a "constitutional instrument of European public order"; (2) human rights litigation is by definition "constitutional"; (3) the ECtHR is increasingly acquiring "constitutional status" in member states; and (4) the ECtHR decides broadly the same kind of issues as a domestic supreme or constitutional court and also in largely similar ways. 
by national courts as well as by the Court of Justice of the European Union (CJEU), or that the Lisbon Treaty commits the European Union (EU) to becoming a party to the ECHR. ${ }^{62}$ It is true that some cases may have created the impression that the ECtHR has placed itself in the position of a supranational court. Examples include the Loizidou case in which it stated that the ECHR is "a constitutional instrument of European public order," ${ }^{63}$ or the Bosphorus case in which the ECtHR claimed that it, and not the CJEU, had the ultimate competence to determine whether EU regulations comply with the convention when applied by member states ${ }^{64}$ However, whatever impression these cases may have left, the ECtHR has, at the same time, acknowledged the limits imposed on its role. It has reiterated on many occassions that it is not a court of fourth instance, as its function is not to deal with errors of fact or law allegedly made by a national court, unless and in so far as they may have infringed rights and freedoms protected by the ECHR, and that it cannot assess the facts that have led a national court to adopt one decision rather than another. ${ }^{65}$

Furthermore, the role of the ECtHR as a European constitutional court is not supported by historical facts. It is evident that the drafters of the ECHR did not envisage that the convention should serve as a constitution for Europe but, rather, as a bulwark against any revival of a totalitarian system of government. ${ }^{66}$ If the ECtHR was to become a European

62 Treaty of Lisbon Amending the Treaty on European Union and the Treaty Establishing the European Community, [2007] OJ C 306.

${ }^{63}$ Loizidou v Turkey (preliminary objections) (1995), 310 ECHR (Ser A) 10.

${ }^{64}$ Bosphorus Hava Yollan Turizm ve Ticaret Anonim Şirketi v Ireland [GC], No 45036/98, [2005] VI ECHR 107 at para 143.

${ }^{65}$ Kemmache v France (no 3), No 1762 1/91 (24 November 1994) at para 44; García Ruiz, supra note 4 at para 28; Centro Europa 7 Srl and Di Stefano v Italy [GC], No 38433/o9, [2012] III ECHR 339 at para 197; see also the dissenting opinion of Judge Costa in Kononov v Latvia [GC], No 36376/o4, [2010] IV ECHR 35 .

${ }^{66}$ JG Merrills and AH Robertson submit that there were two main reasons for an enthusiastic approach to human rights protection in post-war Europe. First, many statesmen of that time "were acutely conscious of the need to prevent any recrudescence of dictatorship in Western Europe" and "were aware that the first steps towards dictatorship are the gradual suppression of individual rights." Second was the present "ideological conflict between East and West." JG Merrills \& AH Robertson, Human Rights in Europe: A Study of the European Convention on Human Rights, $4^{\text {th }}$ ed (Manchester: Manchester University Press, 2001) at 3-4. See further a speech of a member of the Consultative Assembly of the Council of Europe, M Pierre-Henri Teitgen, delivered in 1949, in which he underlined that "an international Court, within the Council of Europe, and a system of supervision and guarantees could be the conscience of which we all have need" having regard to the fact that "democracies do not become Nazi countries in one day" and that "a conscience must exist somewhere which will sound the alarm to the minds of a nation menaced.” M Pierre-Henri Teitgen, Consultative Assembly, Official Reports (August 1949) at $115^{8 .}$ 
constitutional court, it would follow that it would be competent to declare national laws "unconstitutional" in cases of a violation of the ECHR in all member states. But not all member states have incorporated the convention into their constitutional orders, and so there are still discrepancies in this regard. In some countries, such as Denmark, the ECHR only forms part of the ordinary law and can be disregarded if it would impugn the Constitution. ${ }^{67}$ In other countries, the ECHR has been declared to form part of the constitutional order, such as in the Czech Republic, ${ }^{68}$ or to hold a supra-legislative, but infra-constitutional, status, such as in France ${ }^{69}$

The ECtHR, instead of assuming the role of a supranational constitutional court, should rather adhere to the principle of subsidiarity and its role of supervisory jurisdiction. After all, this is the direction that it agreed to follow in the Brighton Declaration ${ }^{70}$ and which is presumed in Protocol No 15 to the ECHR. But the general impression that the ECtHR has been assuming the role of a supreme European human rights court is not surprising in view of the dynamic, or evolutive, interpretation of the ECHR it has adopted. The way national courts take into account and apply the interpretative practice of the ECtHR varies depending on the status of the ECHR within a particular legal order and each state's system of constitutional protection of fundamental rights and freedoms. In this respect, different approaches can be illustrated by examining the examples of France and the Czech Republic - countries with different constitutional histories, different systems of constitutional justice, and different degrees of willingness on the part of the respective constitutional jurisdictions to implement and be influenced by the case law of the ECtHR.

67 See e.g. Gauksdóttir, supra note 6 at 17.

68 See Czech Constitutional Court, Case no Pl ÚS 36/o1 (25 June 2002), published under No $403 / 2002$.

${ }^{69}$ Art 55 of the French Constitution reads: "Treaties or agreements duly ratified or approved shall, upon publication, prevail over Acts of Parliament, subject, with respect to each agreement or treaty, to its application by the other party." The French Council of State stated: "[S]i l'article 55 de la Constitution dispose que 'les traités ou accords régulierement ratifiés ou approuvés ont, dès leur publication, une autorité supérieure a celle des lois sous réserve, pour chaque accord ou traité, de son application par l'autre partie,' la suprématie ainsi conférée aux engagements internationaux ne s'applique pas, dans l'ordre interne, aux dispositions de nature constitutionnelle." Council of State, Decision nos 200286, 200287 (3o October 1998).

70 The Declaration was concluded at the High Level Conference meeting at Brighton on 19 and 20 April 2012 at the initiative of the United Kingdom Chairmanship of the Committee of Ministers of the Council of Europe. The Brighton Declaration sought to amend the ECHR to include the principles of subsidiarity and the margin of appreciation. In order to give effect to certain provisions of the Declaration, Protocol No I 5, supra note 7 , amending the ECHR, was adopted by the Committee of Ministers of the Council of Europe in June 2013 . 


\section{French Approaches to Implementation of the ECHR AND ECtHR} RULINGS

France has a dual judicial system — there are "judicial" (civil and criminal) courts and administrative courts. There are three supreme courts - the Council of State (Conseil d'État), the Court of Cassation (Cour de cassation), and the Constitutional Council (Conseil constitutionnel). The Council of State is the supreme administrative court. It hears appeals against some judgments of administrative tribunals, incuding disputes relating to municipal and cantonal elections. It also has jurisdiction over cases of special importance (for example, with respect to petitions seeking the cancellation of presidential decrees or ministerial acts). Furthermore, it advises the government on the preparation of bills, ordinances, and certain decrees and anwers the government's queries on legal affairs. The Council of State does not have power formally to review legislation for conformity with the Constitution. If it finds legislation that may not be in conformity with the Constitution, it will refer the matter to the Constitutional Council.

The Court of Cassation is the highest court in the French judiciary. It does not judge on the facts but, rather, determines whether laws have been properly applied by the inferior courts. It is not a third level of jurisdiction as it does not rule on the merits of the individual case. Its most important role is the harmonization of the case law in the country. It also gives opinions on new and complex legal issues to other courts. Both the Council of State and the Court of Cassation may review laws and their application for their conformity with the ECHR - that is, they exercise an ex post control of the "conventionality" of laws.

Of the three supreme courts, it is only the Constitutional Council that is entitled to exercise judicial review of the constitutionality of legislation and international treaties and, to some extent, EU directives, whereby their compliance with the French Constitution is ensured. The Constitutional Council, however, does not stand at the top of the hierarchy of ordinary or administrative courts. It is separate from the "judicial" courts and the administrative courts. It deals with disputes over legislation and disputes over elections or referendums and provides advice to the government. It has the power to review legislation for its conformity with constitutional norms. It gives rulings on constitutionality ex ante (that is, it reviews statutes prior to their entry into force) and on preliminary questions of constitutionality (questions prioritaires de constitutionnalitê). The latter may be referred to the Constitutional Council only if the reference is approved by the Council of State or by the Court of Cassation. The decisions of the Constitutional Council are binding on all courts, including the ordinary supreme courts - the Court of Cassation and the Council of State. 
As to the relationship between the Constitutional Council and the ordinary supreme courts (the Court of Cassation and the Council of State), the latter submit preliminary questions of constitutionality to the Constitutional Council in cases of suspected violation of constitutional rights by a statute. Furthermore, the Constitutional Council influences the ordinary supreme courts by means of its case law, as its decisions are binding on all public authorities, including the courts. And, vice versa, the Constitutional Council is influenced by decisions of the ordinary supreme courts and by advisory opinions of the Council of State given in the process of legislative drafting. Another dimension of the indirect relationship between the Constitutional Council and the ordinary supreme courts can be found in respect of the review of conformity of laws with the $E C H R$, which is carried out by the latter courts. In so doing, they run the risk that their review might come into conflict with the Constitutional Council's review of the conformity of laws with the Constitution. As we shall see later in this article, potential differences in the assessment of the conformity of laws with the ECHR, on the one hand, and with the Constitution, on the other hand, seem to be a point of friction in the relationship between the two supreme courts and the Constitutional Council.

\section{STATUS OF THE CONVENTION WITHIN THE LEGAL ORDER OF FRANGE}

Although France was one of the founding states of the Council of Europe to sign the ECHR on 4 November $195^{\circ}$, it only ratified the convention in $1974^{71}$ and allowed individual petitions in $1981 .{ }^{72}$ The delay in ratification was grounded in the government's belief that ratification was unnecessary to secure fundamental rights and liberties that were already guaranteed in national law and that there was no need to become subject to supranational

${ }^{71}$ Décret no 74-36o du 3 mai 1974 portant publication de la Convention européenne de sauvegarde des droits de l'homme et des libertés fondamentales, 3 May 1974.

72 Décret no 8 I-9I 7 du 9 octobre I 98 I portant publication de la déclaration d'acceptation du droit de recours individuel en application de l'art. 25 de la Convention européenne des droits de l'homme en date du o4-I I-I95o et de l'art. 6 du protocole 4 à ladite Convention, en date du I6-o9, 9 October 1981. The ECtHR may receive applications from any person, non-governmental organization, or group of individuals claiming to be the victim of a violation by one of the high contracting parties of the rights set forth in the ECHR or the protocols thereto. It means that natural and legal persons can apply directly to the ECtHR if they believe their human rights have been violated. The ECtHR may hear individual cases without the prior assent of the individual's national government. In 1998, Protocol No I I to the Convention for the Protection of Human Rights and Fundamental Freedoms, Restructuring the Control Machinery Established Thereby, 11 May 1994, Eur TS No 155, made the right of individual petition compulsory. 
control in this area. ${ }^{73}$ In regard to the hierarchy of international engagements and national law in France, the ECHR enjoys a supra-legislative, but infra-constitutional, status. ${ }^{74}$ The French legal order is based on a monist view of the operation of international treaties in the national legal order. ${ }^{75}$ Thus, international treaties acquire an authority superior to that of ordinary laws by virtue of their ratification and publication in the Official Journal.

The ECHR is not part of the rules of reference for the review of constitutionality - that is, constitutional norms (or the so-called "bloc of constitutionality"). The concept of the French "bloc of constitutionality" (bloc de constitutionnalitê) refers to the totality of constitutional norms and principles that are taken into consideration in the framework of the review of the constitutionality of laws by the French Constitutional Council and that must be observed by the executive branch and by Parliament in the exercise of their respective powers. This concept includes not only the $195^{8}$ Constitution and its preamble but also, since 1971, the Declaration of the Rights of Man and of the Citizen, ${ }^{76}$ the preamble of the 1946 Constitution, ${ }^{77}$ and the 2004 Charter of the Environment, to which the preamble of the $195^{8}$ Constitution now refers. Furthermore, it also includes norms referred to by constitutional texts, such as the "fundamental principles

${ }^{73}$ L Heuschling, "Comparative Law and the European Convention on Human Rights in French Human Rights Cases" in E Örücü, ed, Judicial Comparativism in Human Rights Cases (London: British Insitute of International and Comparative Law, 2003) at 26. Heuschling observes: "France being the 'patrie', the birthplace of human rights, and having invented legal monuments such as the Code Civil and the judicial review of the administration by the Conseil d'État, comparative law could only be an export, but never an import. This nationalist pride was one of the arguments used by French governments to delay the ratification of the ECtHR: if the situation of human rights is already perfect in France due to a long-standing tradition, why should there be a need to adopt the Convention and, even more, to submit to the review of the Strasbourg Court?"

${ }^{74}$ Council of State, supra note 69.

${ }^{75}$ Bjorge, supra note 4 at 114 ; Lambert-Abdelgawad \& Weber, supra note $5^{1}$ at 115 .

${ }^{76}$ In the landmark Decision no 71-44 DC (16 July 1971), the Constitutional Council expressly acknowledged that the preamble of the $195^{8}$ Constitution had a constitutional value and, by reference to the principles laid down in the Declaration of the Rights of Man and of the Citizen, French National Constituent Assembly, 26 August 1789, it rejected a law that violated one of those principles. The $195^{8}$ preamble refers to the Declaration, the preamble of the 1946 Constitution, and, since 2005 , the Charter of the Environment. Loi constitutionnelle 2005-205 relative à la Charte de l'environnement, 1 March 2005 at 3697 .

77 The preamble of the 1946 Constitution enumerates social rights or, more precisely, "the political, economic, and social principles" that are "especially necessary to our times." 
recognized by the laws of the Republic" and "political, economic, and social principles" 78 to which the preamble of the 1946 Constitution refers. ${ }^{79}$ In addition, this concept comprises the principles and objectives of constitutional value that, although not being explicitly referred to or enshrined in constitutional texts, are deduced by constitutional judges from these texts by interpretation. This notion of the Constitution in the "broad" sense has been denoted as the "bloc of constitutionality" in the scholarly literature. ${ }^{80}$

78 These principles were recognized by the Constitutional Council in Voluntary Interruption of Pregnancy Act, Decision no 74-54 DC (15 January 1975), [1975] OJ No 13 at 671 [Decision no 74-54], concerning termination of pregnancy. The Constitutional Council held that: "None of the exceptions allowed by the statute is, as matters stand, inconsistent with any of the fundamental principles recognised by the laws of the Republic, nor with the principle set out in the preamble to the Constitution of 27 October 1946 whereby the nation guarantees health care to all children, nor with any of the other principles of constitutional value established by that text; none of the derogations anticipated by the law is contrary to one of the fundamental principles recognized by the laws of the Republic, nor disregards the principle pronounced in the Preamble of the 1946 Constitution according to which the Nation guarantees a child the protection of health. The Voluntary Interruption of Pregnancy Act is not therefore at variance with the texts to which the Constitution of 4 October $195^{8}$ refers in the preamble thereto, nor with any Article of the Constitution." Besides the right to health, the Constitutional Council has also recognized as belonging to this category of principles, e.g., the right to asylum (Constitutional Council, Act on the Control of Immigration and Conditions of Entry, Reception and Residence for Aliens in France (Loi relative à la maîtrise de l'immigration et aux conditions d'entrée, d'accueil et de séjour des étrangers en France), Decision no 93-325 (13 August 1993), [1993] OJ No 19o [Act on the Control of Immigration] ), the right of workers to participate in the management of enterprises (Constitutional Council, Five-year Act on Labour, Employment and Vocational Training (Loi quinquennale relative au travail, à l'emploi et à la formation professionnelle), Decision no 93-328 (16 December 1993), [1993] OJ No 295), or the right to lead a normal family life (Act on the Control of Immigration, ibid). As principles, these were denoted as positive rights or claim rights vis-à-vis the state.

${ }^{79}$ The Preamble of the 1946 Constitution proclaims in paragraph 1 that: "The French people proclaims anew that any human being possesses inalienable and sacred rights, without distinction as to race, religion, or beliefs. It solemnly reaffirms the rights and liberties of man and of the citizen recognised by the Declaration of Rights of 1789 , and the fundamental principles recognized by the laws of the Republic."

${ }^{80}$ The creation of this notion is accredited to Louis Favoreu. He defined the "bloc of constitutionality" as "l'ensemble des principes et règles à valeur constitutionnelle dont le respect s'impose au pouvoir législatif comme au pouvoir exécutif." L Favoreu, Bloc de constitutionnalité, Dictionnaire constitutionnel, sous la dir O Duhamel \& Y Mény (Paris: PUF, 1992) at 87. Georges Vedel developed a double definition of the "bloc of constitutionality" according to which the "bloc of constitutionality" in the narrow sense comprises provisions of constitutional value, and in the large sense all norms superior to law the respect of which is guaranteed by the Constitutional Council. G Vedel, La place de la Déclaration de I 789 dans le "bloc de constitutionnalité": La Déclaration des droits de l'homme et du citoyen et la jurisprudence (Paris: PUF, coll "Recherches politiques," 1989) at 35 . 
There is no hierarchy of constitutional norms forming part of the bloc of constitutionality. Thus, for example, the $195^{8}$ Constitution is not superior to the Declaration of the Rights of Man and of the Citizen and vice versa. Nor does the rule lex posterior derogat legi priori apply. The notion of the bloc of constitutionality has enabled the Constitutional Council to exercise strict control over legislation on the basis of a large number of constitutional principles. The Constitution does not imply that the Constitutional Council should assure the principle of superiority of duly ratified or approved international treaties over statutes in the framework of constitutional review. ${ }^{81}$ Since 1975 , the Council has held that despite the principle of precedence of international treaties over statutes by virtue of Article 55 of the Constitution, it is not competent to examine the conformity of statutes with the ECHR. ${ }^{82}$

In its subsequent decisions, the Council explicitly stated that if review of the superiority of international treaties over statutes could not be exercised within the framework of constitutional review, it must be exercised by ordinary jurisdictions. ${ }^{83}$ Thus, the precedence of the ECHR over national legislation and the effective application of Article 55 of the Constitution are ensured, after some period of hesitation, by the Council of State and the Court of Cassation. In other words, the Council of State and the Court of Cassation review laws for compliance with the ECHR (contrôle de conventionnalité), while the Constitutional Council alone reviews the constitutionality of laws (contrôle de constitutionnalitê). Review for conformity with the $E C H R$ by the former courts "operates as a functional substitute for rights protection under the Constitution." ${ }^{44}$ If the Court of Cassation responded to

${ }^{81}$ Constitutional Council, Act Pertaining to the Opening up to Competition and the Regulation of Online Betting and Gambling (Loi relative à l'ouverture à la concurrence et à la régulation du secteur des jeux d'argent et de hasard en ligne), Decision no 2010-605 DC (12 May 2010), [2010] OJ No o110 at 8897 [Decision no 2010-605].

${ }^{82}$ Decision no $74-54$, supra note 78 , concerning voluntary interruption of pregnancy, "Loi relative à l'interruption volontaire de grossesse." This decision was founded on two arguments. First was an argument based on a strict interpretation of art 61 of the Constitution, which does not confer on the Council the general power of appreciation identical to that of Parliament but only the power to pronounce itself on the conformity of statutes brought before it with the Constitution. If art 55 of the Constitution confers on treaties a superior authority to that of statutes, it does not prescribe or imply that their respect should be guaranteed in the framework of the control of conformity of statutes with the Constitution within the meaning of art 61 of the Constitution. Second, pursuant to the Constitution, the Council is subject to a time limit of one month. It would be difficult to examine within such a short period of time the conformity of statutes with a number of international engagements to which France is party.

${ }^{83}$ Constitutional Council, Loi relative aux conditions d'entrée et de séjour des étrangers en France, Decision no 86-216 DC (3 September 1986), [1986] OJ No 206 [Decision no 86-2 16]; Constitutional Council, Loi de finances pour I 99o, Decision no 89-268 DC (29 December 1989), [1989] OJ No 303 [Decision no 89-268].

${ }^{84}$ Lambert-Abdelgawad \& Weber, supra note $5^{1}$ at 116. 
this invitation rather promptly in a decision of 24 May $1975,{ }^{85}$ the Council of State took almost fifteen years to accept the supremacy of a treaty over a subsequently enacted statute. ${ }^{86}$

Accordingly, the conformity of national law with the ECHR is not assured by means of constitutional review but, rather, by means of review of treaty conformity exercised by ordinary courts that apply the international fundamental rights standards directly. The Constitutional Council reviews only the conformity of laws with the Constitution, and international norms are not norms of reference in this regard. Disregarding the issue of the conformity of legislation with the ECHR in the review of constitutionality, the Council has ruled that "a statute that is inconsistent with a treaty is not ipso facto unconstitutional." ${ }^{\prime 7}$

\section{RELEVANCE OF THE ECHR AND THE CASE LAW OF THE ECHHR IN THE PRACTICE OF THE FRENCH CONSTITUTIONAL COUNCIL}

Although the Constitutional Council does not take into account the ECHR as a norm of reference, it gives it great weight as a source of inspiration for interpreting constitutional norms ${ }^{88}$ The ECHR is an instrument for interpreting the Constitution and for ensuring convergence between national constitutional law and European human rights law. The influence of the ECHR and the ECtHR on the jurisprudence of the Constitutional Council is purely intellectual; it involves the persuasive authority of the jurisprudence of the ECtHR and the inspiration that the Council draws from

85 The Court of Cassation has considered the compatibility of national law with international treaties since the decision in Société des Cafés Jacques Vabre, Cass mixte, 24 May 1975, (1975) Bull civ 497, No 73-13556.

${ }^{86} \mathrm{CE}$, 20 October 1989, Nicolo (1989) Rec 190. Until 1989, the Council of State ensured the prevalence of international law over such national laws that had been adopted before the ratification and incorporation of international treaties into the French legal system. It considered that it would otherwise indirectly monitor conformity of the law with the Constitution, which was the task of the Constitutional Council (e.g., CE, 1 May 1968, Syndicat général des fabricants de semoules de France, (1968) Recueil 149). It changed course in 1989 when it ruled that international norms had to take precedence over national laws, even over those laws adopted after the ratification of international instruments. Having taken into account art 55 of the Constitution, the Council of State for the first time had regard to the Constitutional Council's decision of 1975 .

${ }^{87}$ Decision no 74-54, supra note 78; Decision no 2010-605, supra note 81.

${ }^{88}$ See e.g. J-P Costa, "The Relationship between the European Court of Human Rights and the National Courts" (2013) 3 Eur HRL Rev 264 at 272. D Spielmann, "Jurisprudence of the European Court of Human Rights and the Constitutional Systems of Europe" in M Rosenfeld \& A Sajó, eds, The Oxford Handbook of Comparative Constitutional Law (Oxford: Oxford University Press, 2012) at 1238: "[T] he Convention can nevertheless be considered as a shadow constitution." 
a catalogue of rights that is more recent than the 1789 Declaration of the Rights of Man and of the Citizen. ${ }^{89}$

The dialogue between the Constitutional Council and the ECtHR can be described as a spontaneous dialogue that has been effectuated mostly by the Council implicitly taking into consideration the ECtHR's case law. ${ }^{90}$ This encounter has permitted the latter to enrich the concept of principles and objectives of constitutional value, which can be illustrated in the example of the principle of pluralism. While the French Constitution is silent on this notion, the Constitutional Council, having been inspired by European human rights jurisprudence, ${ }^{91}$ has stated that respect for socio-cultural streams of expression was an objective of constitutional value and one of the conditions of democracy ${ }^{92}$ and that freedom of expression was the turning point in the building of a democratic society. ${ }^{93}$ The Council has also considered that the guarantees provided for by Article 8 of the ECHR could be applied as constitutional principles, in connection with the imposition of administrative sanctions, including in the area of taxation. ${ }^{94}$ This concomitance can also be observed with respect to the rights of the defence, where the Council considered that defence rights were a fundamental principle recognized by the laws of the republic..$^{95}$

The Constitutional Council has also drawn inspiration concerning the emergence of new rights, including the right to respect for private life or the freedom to marry, which constitute, according to the Council, personal liberties guaranteed by Articles 2 and 4 of the Declaration of the

${ }^{89}$ O Dutheillet de Lamothe, "L'influence de la Cour européenne des droits de l'homme sur le Conseil constitutionnel," online: <http://www.conseil-constitutionnel.fr/>.

${ }^{90} \mathrm{~J}$ Andriantsimbazovina, "La prise en compte de la Convention européenne des droits de l'homme par le Conseil constitutionnel, continuité ou évolution?" (2005) 18 Cahiers du Conseil constitutionnel 3 .

${ }^{91}$ Handyside v United Kingdom(1976), 24 ECHR (Ser A) 5.

92 Constitutional Council, Loi relative à la liberté de communication, Decision no 86-217 DC (18 September 1986), [1986] OJ No 218 [Decision no 86-217]; Constitutional Council, Loi relative aux communications électroniques et aux services de communication audiovisuelle, Decision no 2004-497 DC (1 July 2004), [2004] OJ No 159.

${ }^{93}$ Constitutional Council, Loi visant à limiter la concentration et à assurer la transparence financière et le pluralisme des entreprises de presse, Decision no 84-181 DC (10 and 11 October 1984), [1984] OJ No 240.

${ }^{94}$ Constitutional Council, Loi modifiant la loi no 86-1067 du 30 septembre 1986 relative à la liberté de communication, Decision no 88-248 DC ( 17 January 1989), [1989] OJ No 15.

${ }_{95}$ Constitutional Council, Loi renforçant la sécurité et protégeant la liberté des personnes, Decision no 80-127 DC (19 and 20 January 1981), [1981] OJ No 18. In Constitutional Council, Loi relative à la sécurité et à la transparence du marché financier, Decision no 89-26o DC ( 28 July 1989) [Decision no 89-26o], express reference was made to the interpretation of the ECtHR in Delcourt v Belgium (1970), 11 ECHR (Ser A) 1 [Delcourt]. 
Rights of Man and of the Citizen $;{ }^{96}$ the principle of human dignity, which the Council deduced from the preamble to the 1946 Constitution; ${ }^{97}$ and the notion of pluralism of thought and opinion..$^{98}$ Although the ECHR does not form part of the norms of reference for constitutional review, some authors have observed that, despite the persistent refusal of the Council to quote European case law, the standard of protection rendered in the constitutional jurisprudence is largely equivalent to the European one ${ }^{99}$ or in complete conformity with the jurisprudence of the ECtHR. ${ }^{100}$ In some instances. the ECtHR's findings correspond to those delivered by the Council. ${ }^{101}$ In any event, if the Constitutional Council aspires to guarantee the unity of the legal system and legal certainty, it is desirable that it closely take into consideration the jurisprudence of the ECtHR. ${ }^{102}$

Although the Constitutional Council does not, as a matter of principle, expressly refer to judgments of the ECtHR, ${ }^{103}$ it has done so exceptionally in the decision of 19 November 2004 concerning the Treaty Establishing the Constitution for Europe, in which it referred to the judgment of the ECtHR in the case of Leyla Sahin v Turkey with a view to preserving certain values

${ }^{96}$ Respectively: Constitutional Council, Loi portant création d'une couverture maladie universelle, Decision no 99-416 DC (23 July 1999), [1999] OJ No 172 [Decision no 99-416]; Constitutional Council, Loi relative à la maîtrise de l'immigration, au séjour des étrangers en France et à la nationalité, Decision no 2003-484 (20 November 2003), [2003] OJ No 274.

${ }_{97}$ Constitutional Council, Loi relative au respect du corps humain et Loi relative au don et à l'utilisation des éléments et produits du corps humain, à l'assistance médicale à la procréation et au diagnostic prénatal, Decision no 94-343/344 DC (27 July 1994), [1994] OJ No 174.

${ }_{98}$ Decision no 86-217, supra note 92; Constitutional Council, Loi relative à la limitation des dépenses électorales et à la clarification du financement des activités politiques, Decision no 89-271 DC ( 11 January 1990), [1990] OJ No 11.

${ }^{99}$ R Tinière, "Question prioritaire de constitutionnalité et droit européen des droits de l'homme. Entre équivalence et complémentarité" (2012) 28:4 Revue française de droit administratif 621 at 622 .

${ }^{100}$ Lambert-Abdelgawad \& Weber, supra note $5^{1}$ at 137 . The authors note that a wide range of French authorities have expressed profound irritation at the tendency of the ECtHR towards harmonization.

${ }^{101}$ Such as in the case of Célice v France, Decision no 14166/og (8 March 2012) at 36. The ECtHR referred to the Council's findings in Constitutional Council, M. Jean-Yves G. [Amende forfaitaire et droit au recours], QPC Decision no 2010-38 (29 September 2010), [2010] OJ No 0227.

102 Tinière, supra note 99 at 622 ; Dutheillet de Lamothe, supra note 89.

103 O Dutheillet de Lamothe, a former member of the Constitutional Council, submits that in conformity with the French tradition, the Constitutional Council does not expressly refer to rulings of the ECtHR: "[C] onformément à la tradition française, le Conseil constitutionnel ne se réfère pas expressément à d'autres décisions de justice et notamment aux arrêts de la Cour européenne des droits de l'homme." Dutheillet de Lamothe, supra note 89 . 
of the republic. ${ }^{104}$ With respect to the recent jurisprudence of the Council, the influence of the ECtHR on the amendment of legislation can be perceived in various fields of law. To cite an example, the declaration of non-conformity with the Constitution of legislative provisions on police detention (garde à vue $)^{105}$ was followed by reform of the legislation. ${ }^{106} \mathrm{In}$ procedural issues, the Council has had to recognize the right to an effective legal remedy within the meaning of Article 6 of the $E C H R^{107}$ and that respect for the rights of the defence implies the existence of a just and equitable process and the related necessity of the equality of arms of the parties. ${ }^{108}$

It should not be omitted that the judgments of the ECtHR finding a violation also have an impact on the reopening of judicial proceedings in criminal matters. The French Code of Criminal Procedure ${ }^{109}$ allows for

${ }^{104}$ Constitutional Council, Traité établissant une Constitution pour l'Europe, Decision no 2004505 (19 November 2004), [2004] OJ No 273. This decision concerned the principle of secularism, which is a value of the republic recognized in art 1 of the Constitution. Within the framework of the review of conformity of the Constitution with the Treaty Establishing the Constitution for Europe, [2004] OJ C310/o1, the Council interpreted this principle on the basis of the case law of the Court of Justice of the European Union (CJEU) in order to conclude that art II-70 of the Treaty was compatible with the principle of secularism enshrined in art 1 of the French Constitution. Leyla Sahin v Turkey [GC], No 44774/98, [2005] XI ECHR 173.

105 Constitutional Council, M. Daniel Wet autres [Garde à vue], Decision no 2010-14/22 QPC (30 July 2010), [2010] OJ No 175 .

${ }^{106}$ Law no 2011-392 on Police Detention (Loi relative à la garde à vue) (14 April 2011), reprinted in Journal officiel de la République française (15 April 2011 ) at 6610.

${ }^{107}$ Decision no 99-416, supra note 96.

${ }^{108}$ Decision no 89-26o, supra note 95, on the basis of the judgment in Delcourt, supra note 95; Golder, supra note 38.

${ }^{109}$ Le Code de procédure pénale:

Article 622-1

Le réexamen d'une décision pénale définitive peut être demandé au bénéfice de toute personne reconnue coupable d'une infraction lorsqu'il résulte d'un arrêt rendu par la Cour européenne des droits de l'homme que la condamnation a été prononcée en violation de la Convention européenne de sauvegarde des droits de l'homme et des libertés fondamentales ou de ses protocoles additionnels, dès lors que, par sa nature et sa gravité, la violation constatée entraîne, pour le condamné, des conséquences dommageables auxquelles la satisfaction équitable accordée en application de l'article 41 de la Convention précitée ne pourrait mettre un terme.... [The reconsideration of a final criminal decision may be requested for the benefit of any person judged guilty of an offence, where this conviction is held, in a judgment given by the European Court of Human Rights, to have been declared in violation of the provisions of the Convention for the Protection of Human Rights and Fundamental Freedoms, or its additional Protocols, and where the declared violation, by its nature or seriousness, has led to harmful repercussions for the convicted person, which the just satisfaction granted under article 41 of the Convention cannot bring to an end.] 
the reopening of cases at the request of the minister of justice, the advocate-general of the Court of Cassation, or the person convicted, but only for a finding of guilt rendered by a court dealing with the substance of the case ${ }^{110}$ or by the Court of Cassation. ${ }^{111}$ According to the latter, a condition is that the relationship between the violation and the condemnation must stem from an ECtHR decision. ${ }^{112}$ The case law of the ECtHR, however, has not induced a reopening in civil and administrative law matters.

However, since the Constitutional Council has decided to disregard the ECHR in the process of constitutional review, why does it have recourse to it in the interpretation of constitutional norms? This may be explained by its quest for safeguarding legal certainty in the legal order, given that the other supreme courts - the Council of State and the Court of Cassation - are bound to conform to the jurisprudence of the Strasbourg court to avoid being condemned for a violation of the ECHR. ${ }^{113}$ The more so with regard to the fact that the ECHR is an ever-evolving "living instrument" that is dynamically interpreted by the ECtHR to keep up with the changing social and economic environment in the states parties to the convention. ${ }^{114}$ Consequently, the Council cannot afford to lag behind the ECtHR's evolving case law in order, first, to preserve coherence in the decision-making of the supreme courts and, second, to avoid that France be sanctioned by the Strasbourg court for potential violations of the ECHR.

But is inspiration by the ECHR and the ECtHR's case law for the purpose of interpretating constitutional norms sufficient to prevent potential conflicts between the findings of the Constitutional Council, on the one hand, and those of the ECtHR and the ordinary supreme courts, on the other hand, and to safeguard the related legal certainty? This leads to an analysis of the problems connected with the absence of review for conformity with the ECHR.

${ }^{110}$ E.g., in the case of Hakkar $v$ France, No 3019o/96 (27 November 1996), the ECtHR found a violation of art 6 , paras $3(\mathrm{~b})$ and (c) in conjunction with art 6 , para 1 of the $E C H R$, in that in the context of criminal proceedings before the Assize Court of Yonne, as a result of which the applicant was sentenced to life imprisonment, the applicant had not been given the time or the facilities necessary to prepare his defence and was not represented at the trial. Following the ECtHR's judgment, the applicant lodged an application for re-examination of the judgment of the Yonne Assize Court together with a request for suspension of his sentence. The Re-examination Board accepted the application to re-examine the life sentence and referred the case to the Hauts de Seine Assize Court to undertake a new trial.

111 Cass, Commission réexamen, ${ }_{5} 5$ February 2001, (2001) Voisine, Dall 983.

112 Cass, Commission réexamen, 8 November 2001, (2002) Dall 373.

113 Lageot, supra note $5^{\text {o. }}$

114 See e.g. D Rook, Property Law and Human Rights (London: Blackstone, 2001) at 42-43. 
PROBLEMS ATTACHED TO THE ABSENCE OF REVIEW FOR CONFORMITY WITH THE ECHR BY THE FRENCH CONSTITUTIONAL COUNCIL

A question arises as to whether the implementation of the ECHR as a "living instrument" is effective when the Constitutional Council does not review legislation for conformity with the convention. The question of effectiveness of the implementation of the convention's case law, disregarding the normative text thereof, in view of the fact that it protects rights and freedoms that are basically identical to those protected under the French Constitution, may also arise due to the duality of review and due to the fact that the Constitutional Council does not exercise the power to strike down laws that are in conflict with the ECHR, whereby it could directly eliminate, as well as prevent, possible interferences with the convention. What are the consequences, then, of the Council's refusal to deal with the issue of conformity of statutes with the convention?

The consequences are twofold. First, they encompass a potential clash between the decisions of the Constitutional Council and the ECtHR. From the fact that the Constitutional Council does not apply the ECHR directly to strike down laws that are incompatible with it, a situation may arise where the Council rules on compatibility of national law with the Constitution, while the ECtHR comes to a contrary conclusion and finds a violation of the convention. Romain Tinière notes in this regard that the existing principal dissimilarities between constitutional review and external review for conformity with the ECHR exercised by the ECtHR can be linked to the different tasks that these two jurisdictions are entrusted with, implying that the Constitutional Council is primarily a constitutional judge rather than a human rights judge. ${ }^{115}$ Second, they cover situations of a potential clash between decisions of the Constitutional Council and ordinary courts exercising the power of review of conformity with the ECHR - that is, situations where the Council's decision on constitutionality conflicts with a decision of the ordinary courts on conformity with the convention as well as situations of a potential normative conflict between national law, as such, and the convention.

The first situation can be illustrated in a case of "legislative validations," in which the Constitutional Council was made to modify its jurisprudence concerning a situation where the ECtHR declared a statutory provision that had been held constitutional by the Council contrary to the convention. ${ }^{116}$ In Decision No. 93-332 of 13 January 1994, the Council ruled

115 Tinière, supra note 99 at 623 .

116 The French legislature may adopt a (retrospective) "validating statute" (une loi de validation) by which it renders retroactively legal ("validates") an administrative act that the administrative court had previously held to be illegal or that is susceptible of being illegal. 
on the conformity of Article 85 of the Act of I 8 January I994 with the Constitution. The provision at issue validated the amount of the so-called special difficulties allowance introduced in 1953 for staff of the social security bodies administering the general social security scheme and their dependent institutions in the departments of Alsace-Moselle. The ECtHR, however, referring to its established case law, ruled in the case of Zielinski, Pradal, Gonzales and others v France that Article 85 was contrary to Article 6, paragraph 1 of the ECHR. ${ }^{117}$ It stated that the principle of the rule of law and the notion of a fair trial enshrined in Article 6 precluded any interference by the legislature - other than on compelling grounds of the general interest - with the administration of justice designed to influence the judicial determination of a dispute. According to the ECtHR, Article 85 expressly excluded from its scope those court decisions that had become final on the merits and that settled, once and for all and retrospectively, the terms of the dispute before the ordinary courts. The ECtHR considered that the Constitutional Council's decision did not suffice to establish that Article 85 of the Act of I 8 January I 994 was in conformity with the ECHR. Subsequently, the Constitutional Council rendered a decision in which it adapted its jurisprudence to accord with that of the ECtHR. ${ }^{118}$ It explicitly relied on the principle of the separation of powers in the exercise of the review of proportionality between general interest and interference with the right to recourse. Since then, in regard to legislative validations, the Council exhibits greater vigilance in the appreciation of sufficiency of the general interest in time ${ }^{119}$ and space. ${ }^{120}$

This evolution shows that originally the jurisprudence of the Constitutional Council was less demanding than that of the ECtHR. One can also perceive that the jurisprudence of the Council and the ECtHR on the protection of fundamental rights and freedoms is largely congruent and that the Constitutional Council and the ECtHR, in fact, protect the same rights. ${ }^{121}$ Even so,

117 Zielinski and Pradal and Gonzalez and Others v France [GC], No 24846/94, [1999] VII ECHR 95.

118 Constitutional Council, Loi de financement de la sécurité sociale pour 20oo, Decision no 99-422 DC (2 1 December 1999a), [1999] OJ No 302.

119 Constitutional Council, Loi organique portant validation de l'impôt foncier sur les propriétés bâties en Polynésie française, Decision no 2002-458 DC (7 February 2002), [2002] OJ No 36 .

${ }^{120}$ Constitutional Council, Loi de programmation pour la cohésion sociale, Decision no 2004-509 DC (13 January 2005), [2005] OJ No 15 .

${ }^{121}$ F Luchaire, "Le Conseil constitutionnel et la Convention européenne des droits de l'homme" (2007) 161 Gazette du Palais 11. It can be claimed that due to the attachment of both the Constitutional Council and the ECtHR to the liberal tradition, they have a convergent conception of fundamental rights and freedoms in that the latter represent a limitation of power. 
the fact that they protect the same rights does not acquit the Council of the obligation to maintain the standard degree of protection set up by the ECHR and its case law.

In regard to the second situation involving a potential conflict of national norms with the ECHR, the ordinary courts do not hesitate to resolve it in favour of the latter. The Council of State ${ }^{122}$ and the Court of Cassation ${ }^{123}$ consider that Article 55 of the Constitution provides for the precedence of international law over domestic law, although not over the Constitution. Both of these courts may refuse to apply national legislation in order to ensure the primacy of international instruments. They do not hesitate to refer to the provisions of the ECHR in their judicial review. For example, the Council of State has applied Article 8 of the ECHR with respect to the law of aliens, ${ }^{124}$ and it has referred to Article 6 of the ECHR when ruling on the state's liability in a case of conflicting national law. ${ }^{125}$ However, it was reluctant to recognize the application of Article 6 of the convention in the field of administrative procedure by ruling that an administrative authority could not be considered a tribunal within the meaning of Article 6 of the convention. ${ }^{126}$

Thus, given the absence of review of conformity with the ECHR by the Constitutional Council, when a law is not in conformity with the convention, though it is in conformity with the Constitution, a judge is obliged to refrain from its application. Only an indirect remedy to such a drawback provides a constitutional reform introducing an ex post review of the constitutionality of statutes, as we will see in the next section. ${ }^{127}$

\section{CONSEQUENCES OF AN EX POST REVIEW OF CONSTITUTIONALITY}

At present, the Constitutional Council performs two forms of constitutional adjudication. First, since 1975, it has exercised a constitutional review function that is both ex ante, in the framework of which statutes

122 See CE, Ass, 30 October 1998, Sarran, Levacher et autres, (1998) Rec 369.

${ }^{123}$ See Cass, Ass Plén, 2 June 200o, Mlle Fraisse, (2000) Bull 7, No 4.

${ }^{124}$ CE, Ass, 30 November 2001, Ministre de la Défense v Diop and Ministre de l'économie, des finances et de l'industrie v Diop, (2001) Rec 605.

${ }^{125}$ CE, 9 February 2007, Gardedieu, (2007) Rec 78.

${ }^{126}$ See CE, Ass, 3 December 1999, Didier, (1999) Rec 399.

127 Constitutional Act no 2008-724 (23 July 2008) inserted into the Constitution, art 61-1 and amended art 62 to introduce a special procedure for an a posteriori review of the constitutionality of statutes, which came into force on 1 March 2010. Its purpose was threefold: (1) to vest a new right in a person coming under the jurisdiction of the courts enabling him or her to avail him- or herself of the rights which are conferred on him or her by the Constitution; (2) to remove unconstitutional provisions from the national legal order; (3) to ensure the paramountcy of the Constitutional Council in the national legal order. 
may be referred to the Council before their promulgation, and, if found unconstitutional, do not enter into force; and abstract, since statutes can be referred to the Council only by political authorities. ${ }^{128}$ The Council, thus, engages in prior review of the constitutionality of laws. ${ }^{129}$ This type of review is in place since the founders of the $195^{8}$ Constitution designed the Constitutional Council as a means of securing executive dominance over Parliament and not to protect fundamental rights, as some claim. ${ }^{130}$ Second, since 2010 , the Constitutional Council has exercised a new form of constitutional review that is ex post, as it concerns statutes already enacted and concrete, since a person to whom a statute is being applied has the possibility of making "an application for a priority preliminary ruling on the issue of constitutionality" of the statute (question prioritaire de constitutionnalité (QPC)). The QPC does not provide for the lodging of a constitutional complaint directly before the Constitutional Council; it "only gives the exclusive right to have one's case examined for an eventual transmission"131 by the Council of State or the Court of Cassation. ${ }^{132}$

Although the QPC does not change anything regarding the role of the $E C H R$ in constitutional review or its subordinate position to the Constitution in the French legal order, it, nevertheless, affords an indirect remedy to the absence of review for conformity with the convention by the Constitutional Council. The indirect remedy consists in the power of the

128 The president of the republic, the prime minister, speakers of both Chambers of Parliament and, in most cases, by at least sixty deputies or sixty senators.

129 The binding character of its decisions is limited to the concrete issue on which the Council rules. The consequences of a finding of unconstitutionality of a statute or its provisions is that it may not be promulgated and, in regard to international agreements, the statute providing empowerment to conclude or ratify the agreement may only be adopted after amendment of the Constitution.

${ }^{130}$ Lambert-Abdelgawad \& Weber, supra note $5^{1}$ at 144 .

131 O Pfersmann, “Concrete Review as Indirect Constitutional Complaint in French Constitutional Law: A Comparative Perspective" (2010) 6 European Constitutional Law Review 223 at 237. Any person subjected to the jurisdiction of the courts has the right to argue in support of his claim that a statutory provision infringes the rights and freedoms guaranteed by the Constitution. An application to this effect may be lodged before all courts and at every stage of proceedings. The incumbent court will decide whether the application is admissible and if so, it will then transmit the application to the Council of State or the Court of Cassation that are vested with the power to decide whether this issue of constitutionality should be referred to the Constitutional Council.

132 The QPC can only be referred to the Constitutional Council by the two supreme courts, the Court of Cassation and the Council of State. Art 61-1 of the Constitution stipulates that, " $[w]$ hen during proceedings before a Court of Law, it is claimed that a statutory provision infringes the rights and freedoms guaranteed by the Constitution, a referral may be made to the Constitutional Council by the Conseil d'État or the Cour de cassation, and the Constitutional Council shall give its ruling within a specified time." 
Constitutional Council to abrogate a challenged statute or its provision which the Council finds unconstitutional, ${ }^{133}$ and, hence, to prevent possible inconsistencies of a national law with the ECHR (which could possibly give rise to an adverse ruling by the ECtHR); and, further, in the new competence of the Council of State and the Court of Cassation to refer QPCs to the Constitutional Council. It is no longer necessary to undergo review of the conformity of the law with the ECHR in order to set aside a statute incompatible with the Constitution. By abrogating laws that are incompatible with the Constitution, the Council prevents possible present or future discrepancies between national law and the ECHR and, hence, potential future rulings of the ECtHR on a violation of the convention, which renders the interaction between these two institutions more effective. The question of validity of a contested statutory provision or a statute will not be subjected to a new proceeding on appeal, cassation, or before the ECtHR, notwithstanding whether the contested statute was declared to be in conformity with the ECHR by the Council of State or the Court of Cassation. ${ }^{134}$ Moreover, the introduction of the QPC has brought about a new dimension in relations between the ECtHR and the Constitutional Council. It has opened up the possibility of scrutinizing the Council's decisions in light of the exigencies of Article 6 of the ECHR (the fair trial guarantee). Previously, this provision did not apply to the practice of the Constitutional Council since Article 6 of the ECHR does not apply to ex ante or abstract constitutional review, as there was no civil litigation or parties. ${ }^{135}$

133 According to art 62 of the Constitution, "[a] provision held to be unconstitutional on the basis of Article 61-1 shall be repealed as from the publication of the decision of the Constitutional Council or at a subsequent date as specified by said decision. The Constitutional Council shall determine the conditions in and extent to which the effects of the challenged decision shall be liable to be called into question." See e.g. Constitutional Council, Loi organique relative à l'application de l'article 6 I-I de la Constitution, Decision no 2009-595 DC (3 December 2009).

${ }^{134}$ Constitutional Council, Consorts L [Cristallisation des pensions], Decision no 2010-1 QPC (28 May 2010), [2010] OJ No 122; Constitutional Council, Région Languedoc-Roussillon et autres [Article 575 du code de procédure pénale], Decision no 2010-15/23 QPC (23 July 2010), [2010] OJ No o169; Constitutional Council, M. Daniel W et autres [Garde à vue], Decision no 2010-14/22 QPC (30 July 2010), [2010] OJ No 0175.

${ }^{135}$ David Szymczak, "Question prioritaire de constitutionnalité et Convention européenne des droits de l'Homme: l'européanisation 'heurtée' du Conseil constitutionnel français," Jus Politicum, online: <http://juspoliticum.com/article/Question-prioritairede-constitutionnalite-et-Convention-europeenne-des-droits-de-l-Homme-l-europeanisationheurtee-du-Conseil-constitutionnel-francais-449.html> ; Marc Guillaume, "Question prioritaire de constitutionnalité et Convention européenne des droits de l'homme," Nouveaux Cahiers du Conseil constitutionnel no 32 (Dossier: Convention européenne des droits de l'homme), online: <http://www.conseil-constitutionnel.fr/conseil-constitutionnel/ francais / nouveaux-cahiers-du-conseil/cahier-n-32/question-prioritaire-deconstitutionnalite-et-convention-europeenne-des-droits-de-l-homme.9905 $6 . \mathrm{html}>$. 
The QPC, however, does not respond to the potential for jurisprudential conflicts between the Constitutional Council, on the one hand, and the ordinary supreme courts and the ECtHR, on the other, with respect to the compatibility of national law with the ECHR. If the Constitutional Council holds that the contested law is constitutional, it will continue to exist in the national legal order. The ordinary supreme courts will have to apply it, unless they find it incompatible with a provision of an international treaty or the law of the EU. ${ }^{136}$ Thus, although the ordinary supreme courts have become subsidiary judges of the constitutionality of laws by exercising their role as a "filter" for QPCs, they continue to be the judges of conformity with the $E C H R$, without, however, the power to repeal a statute due to its incompatibility with the convention. The ordinary supreme courts seem to continue to be caught in a vice between the Constitutional Council, on the one hand, and the ECtHR, on the other. In this dilemmatic situation, they do not hesitate to diverge from the Constitutional Council, displaying their autonomy, as illustrated by a case pertaining to the presence of counsel during police detention (garde à vue).

In this case, the Constitutional Council entered into conflict with an interpretation of the ECtHR. The Constitutional Council ruled that the legal regime of police detention, in regard to the limitation of the presence of counsel with respect to certain criminal offences, had already been held to be in conformity with the Constitution, ${ }^{137}$ while finding other contested provisions of the Code of Criminal Procedure unconstitutional. ${ }^{138}$

136 The power of the ordinary supreme courts to review compatibility of laws with an international treaty or the law of the European Union is implied in the case law of the Constitutional Council. In 1975, the Council held that despite the principle of precedence of international treaties over statutes by virtue of art 55 of the Constitution, it was not competent to examine the conformity of statutes with France's international and European commitments (Decision $74-54$, supra note 78 ). In its subsequent decisions, the Council explicitly stated that the review of compatibility of laws with international treaties must be exercised by ordinary courts under the control of the Court of Cassation and the Council of State (Decision no 86-216, supra note 83; Decision no 89-268, supra note 83). The Court of Cassation, not long after the Constitutional Council's decision of 1975, considered that Article 95 of the then EEC Treaty (now the EU Treaty) prevailed over the relevant national legislation. Subsequently, the Council of State also considered, for the first time in 1989, that the EEC Treaty prevailed over national legislation (the Act of 1977 on Organisation of European Parliamentary Elections). For further reading, see Lageot, supra note $5^{\mathrm{O}}$ at $15^{8-59}$.

137 Constitutional Council, Loi portant adaptation de la justice aux évolutions de la criminalité, Decision no 2004-492 DC (2 March 2004), [2004] OJ No 59.

${ }^{138}$ Constitutional Council, M. Daniel Wet autres [Garde à vue], Decision no 2010-14/22 QPC (30 July 2010), [2010] OJ No 0175. The Constitutional Council considered that arts 62, 63,77 of the Code of Criminal Procedure were contrary to the Constitution as they did not permit a person who was being interrogated while in police detention to avail themselves of the effective assistance of counsel. 
The case law of the ECtHR, on the contrary, requires the presence of counsel during detention, save for exceptions justified by particularly pressing reasons and not depending on the nature of the crime in question. ${ }^{139}$ The Constitutional Council ruled that the challenged provisions found to be unconstitutional would remain in effect until 1 July 2011, after a new law was to be adopted, thereby suspending the effect of the declaration of unconstitutionality to that date. ${ }^{140}$ The criminal chamber of the Court of Cassation, undertaking the review of conformity of the same provisions of the Code of Criminal Procedure with the ECHR, upheld the conclusion of the Constitutional Council to suspend the effects of non-conformity with the ECHR until the legal regime of police detention was modified by law on 1 July 2011 at the latest. ${ }^{141}$

A few days before the Court of Cassation rendered its decision, the ECtHR delivered a judgment condemning France for the practice that had been challenged before the Constitutional Council and the Court of Cassation. ${ }^{142}$ The plenary assembly of the Court of Cassation, taking into account the condemning judgment of the ECtHR, refused to follow the decision of the criminal chamber below and ruled on 15 April 2011 in favour of the immediate application of the $E C H R$ with a view to preventing the risk of systematic condemnations of France by the ECtHR in future. ${ }^{143}$ The Court of Cassation, thus, largely neutralized the postponed effect of the declaration of unconstitutionality by giving immediate effect to the declaration of non-conformity with the convention and, in so doing, interfered with the authority of the Council's decision that is binding on all national jurisdictions.

${ }^{139}$ Notably in the case of Brusco v France, No 1466/o7 (14 October 2010) [Brusco], the ECtHR stated that "the person held in custody has the right to be assisted by a counsel from the beginning of custody as well as during interrogations." See also Salduz v Turkey, No 36391/o2 (27 November 2008) or Dayanan v Turkey, No 7377/o3 (13 October 2009). On the basis of European case law (Muller v France, No 21802/93, [1997] II ECHR 11), the legislation on the garde à vue had already been modified in 2000 and 2002 in regard to its duration. The reform (Law no 2000-5I 6 on Presumption of Innocence and Law ("Loi Perben"), 2002) reinforced the procedural guarantee in the application of legislation on the measure of garde à vue and created the office of juge des libertés et de la détention competent to decide on the appropriateness of such measure.

140 The Constitutional Council held that "l'abrogation immédiate des dispositions contestées méconnaîtrait les objectifs de prévention des atteintes à l'ordre public et de recherche des auteurs d'infractions et entraînerait des conséquences manifestement excessives; qu'il y a lieu, dès lors, de reporter au 1er juillet 2011 la date de cette abrogation afin de permettre au législateur de remédier à cette inconstitutionnalité."

${ }^{141}$ Cass crim, 19 October 2010, (2010) Bull crim 673, Nos 10-82.306,10-85.051, 10-82.902.

142 Brusco, supra note 139.

143 Cass, Ass plén, 15 April 201 1, (2011) Bull crim 1, No 10-17.049. 
This case demonstrates that constitutional review and the review of conformity of laws with the ECHR have not ceased to interfere with one another, despite the introduction of the QPC, which purported to mitigate these interferences. In this context, Sébastien Platon notes that this practice may lead the applicants to develop a "more beneficial litigious strategy" by having recourse to the ordinary courts with a claim of non-conformity of a law with the ECHR to obtain the law's immediate inapplicability, even where the constitutional court has decided to suspend abrogation of the law that it has found to be in conflict with a fundamental right or liberty. ${ }^{144}$ In any event, the decision of the ordinary judges does not have the same effect as that of the Constitutional Council, as the former entails only the relative inapplicability of legislative provisions found not to be in conformity with the ECHR.

It can be claimed that the QPC preserves the pre-existing isolation of constitutional review from the international context. The consequences that arise therefrom only confirm what has already been discussed that is, the potential for clashes in the courts' findings and the resulting weakening of legal certainty as well as a constitutional "autonomy" that is disconnected from the European context and, thus, excluded from dialogue with ECtHR judges. Potential conflicts would be prevented if the Constitutional Council reviewed laws both for constitutionality and conformity with the ECHR. This would also lead to a more coherent interpretation and application of the norms and jurisprudence of the ECHR at the national level and to a closer synergy between the Constitutional Council and the ECtHR. Yet, review of laws for conformity with the ECHR by the Council would be "toothless" if the latter did not have the power to render normative provisions inoperative due to their conflict with the convention. This would require that, in the hierarchy of norms, the ECHR be endowed with the same legal force as the Constitution, such as has been established by the Czech Constitutional Court.

\section{CZech Approaches to Implementation of the ECHR And ECtHR RULINGS}

STATUS OF THE CONVENTION WITHIN THE LEGAL ORDER OF THE CZECH REPUBLIC

In regard to the position of international treaties in the Czech legal order, until the entry into force of the so-called Euro-amendment of the

${ }^{144}$ S Platon, "Les interférences entre l'office du juge ordinaire et celui du Conseil constitutionnel: 'malaise dans le contentieux constitutionnel'?" (2012) 28:4 Revue française de droit administratif 639 at 645 . 
Constitution on 1 June $2002,{ }^{145}$ international human rights treaties, including the ECHR, were directly applicable and took precedence over national law. ${ }^{146}$ The Euro-amendment abolished this special category of human rights treaties by amending Articles 10 and 87, paragraph 1 (a) and (b) of the Constitution, ${ }^{147}$ which referred to these treaties as norms of reference for the review of the constitutionality of laws by the Constitutional Court. The new wording of Article 10 of the Constitution introduced an incorporation clause relating to all international treaties, including human rights treaties. ${ }^{148}$ A grammatical interpretation of Article 10 would lead one to think that it is the ordinary courts that are competent to review laws for compatibility with international treaties and that are entitled to give priority of application to an international treaty in case of conflict. The Czech Constitutional Court, however, has refuted any considerations to this effect. Shortly after the promulgation of the Euro-amendment, it rendered a judgment in which it held that "no amendment to the Constitution can be interpreted to the intent that it would lead to a limitation of the already achieved level of procedural protection of fundamental rights and freedoms." ${ }^{149}$ It further stressed that the ratified and promulgated international human rights treaties formed part of the constitutional order of the Czech Republic and that the incorporation clause could not be interpreted to mean that these international treaties would cease to be norms of reference in the review of the constitutionality of domestic laws by the Constitutional Court.

145 Constitutional Act No 395/2001 Coll ("ústavní zákon č 395/2001 Sb, kterým se mění ústavní zákon České národní rady č 1/1993 Sb, Ústava České republiky, ve znění pozdějších předpisư”).

${ }^{146} \mathrm{~J}$ Malenovský, Mezinárodni právo veřejné: jeho obecná část a poměr $\mathrm{k}$ jiným právním systémům, zulášě k právu českému (Public International Law: the General Part and the Relationship to Other Legal Systems, Especially to the Czech Law) (Brno: Masaryk University, 2008) at 464-71.

147 The Euro-Amendment entirely reformulated art 10 of the Constitution, which provided that only international treaties concerning human rights and fundamental freedoms that have been duly ratified and promulgated take precedence over statutes. The current art 10 reads as follows: "Promulgated treaties to the ratification of which Parliament has given its consent and by which the Czech Republic is bound, form part of the legal order; shall a treaty provide differently from a statute, the treaty shall apply." Art 87, paras 1 (a) and (b) of the Constitution read as follows: "(1) The Constitutional Court has jurisdiction: a) to annul statutes or individual provisions thereof if they are in conflict with the constitutional order; b) to annul other legal enactments or individual provisions thereof if they are in conflict with the constitutional order or a statute."

148 The current text of art 10 of the Constitution reads as follows: "Promulgated international treaties, the ratification of which has been approved by Parliament and which are binding on the Czech Republic, shall constitute a part of the legal order; should an international treaty contain a provision contrary to a law, the international treaty shall be applied."

149 Constitutional Court no Pl ÚS $36 / 01$ (25 June 2002), No 403/2002. 
Accordingly, although it appears from Article 10 of the Czech Constitution that promulgated and ratified international treaties are of supralegislative value and have priority of application over conflicting statutes, the Constitutional Court has interpreted this provision in such a way that international human rights treaties form part of the constitutional order and are norms of reference in the review of the constitutionality of laws. The Constitutional Court, thus, adopted an expansive interpretation of the constitutional order under Article 112, paragraph 1, of the Constitution, whereby it argued that the scope of the notion of the constitutional order cannot be interpreted only in light of Article 112 , paragraph 1, of the Constitution but must also take account of Article 1, paragraph 2, according to which the Czech Republic honours its obligations under international law. This decision was largely criticized in the scholarly literature as judicial activism encroaching on legislative power and as an impermissible overstepping of the competences of the court in enlarging the scope of Article 112 , paragraph 1, of the Constitution. ${ }^{150}$ Even so, the Constitutional Court reiterated its stance in its subsequent case law. ${ }^{151}$

It follows from the jurisprudence of the Constitutional Court that the $E C H R$ has been "constitutionalized" to form part of the norms of reference for the review of constitutionality and part of the Czech constitutional order. As a consequence, any conflict with the ECHR on the part of national authorities entails a conflict with the Czech Constitution. The Constitutional Court may then avail itself of its competence to strike down the conflicting statute or other legal regulation or a conflicting individual decision of a public authority.

\section{RELEVANCE OF THE ECHR AND THE CASE LAW OF THE ECTHR IN THE PRACTICE OF THE CZECH CONSTITUTIONAL COURT}

With respect to the approach of the Constitutional Court towards final judgments of the ECtHR, one of the former judges of the Constitutional Court, in his report at a seminar of the Venice Commission on "The Value of Precedents (National, Foreign, International) for Constitutional Courts,"

${ }^{150}$ J Filip, "Nález č 403/2002 Sb jako rukavice hozená ústavodárci Ústavním soudem" (2002) 3:1 1 Právní zpravodaj 11 at 12-15;V Sládeček, Ústavní soudnictví, 2nd ed (Prague: CH Beck, 2003) at 104-o6; J Malenovský, "Euronovela Ústavy: 'Ústavní inženýrství' ústavodárce nebo Ústavního soudu či obou?” in J Kysela, ed, Deset let Ústavy České republiky: východiska, stav, perspektivy (Prague: Eurolex Bohemia, 2003) 173.

${ }^{151}$ See Constitutional Court no Pl ÚS 34/O2 (5 February 2003); Constitutional Court no I ÚS 752/02 (15 April 2003); Constitutional Court no Pl ÚS 44/o2\#1 (24 June 2003); Constitutional Court no Pl ÚS 44/o3 (5 April 2005). In Inequality within Bankruptcy Act, the Constitutional Court annulled a part of the Bankruptcy Act for its inconsistency with art 1 of Protocol No I Amending the Convention for the Protection of Human Rights and Fundamental Freedoms: Inequality within Bankruptcy Act, Pl ÚS 44/o2, no 1 (24June 2003). 
observed: "The case law of the Czech Constitutional Court generally reflects that of the European Court of Human Rights. There are no great differences between them, nor is there any noncritical application."152 The Constitutional Court itself has described its stance vis-à-vis the case law of the ECtHR as follows: "The Constitutional Court does not cast any doubt on the content of a binding judgment of the European Court in the cases against the Czech Republic representing a commitment of the Czech Republic which follows from international law. The Czech Republic is obliged to abide by such commitments not only under international law, but also under Article 1 para. $2^{153}$ of the Constitution." 154 Thus, apart from the international commitment undertaken in the ECHR, the obligation to abide by judgments of the ECtHR and to implement them flows directly from the Czech Constitution. The Constitutional Court draws its competence for implementing the ECtHR's case law from Article 87, paragraph 1 (i), of the Constitution, pursuant to which it "shall rule on measures essential for the implementation of a ruling by an international court, which is binding for the Czech Republic, unless it can be implemented in a different manner."

The Constitutional Court has also expressed itself on the importance of interpretation of the ECHR by the ECtHR for national authorities. It has considered that the relevance of the ECtHR's judgments reaches "constitutional quality" in Czech law and that "public authorities have a general duty to take into account the interpretation of the European Convention by the European Court in the cases brought before the Court against the Czech Republic, as well as in those concerning other member states of the Convention if the nature of the latter also makes them important for the interpretation of the Convention in the Czech context." ${ }^{155}$ The Constitutional Court takes into account the case law of the ECtHR and quotes it on a regular basis. Since the ECHR was declared by the Constitutional Court to form part of the constitutional order — or the Constitution, in the larger sense - the Constitutional Court has also referred to it when striking down parts of statutes or statutory provisions for their incompatibility with the ECHR. Since the ECHR is directly applicable, the ECtHR has

${ }^{152}$ S Balík, "A Few Notes on the Case Law of the Czech Constitutional Court, the European Court of Human Rights and the European Court of Justice and Its Role in the Czech Republic: Report 2004" (Seminar on the Value of Precedents (national, foreign, international) for Constitutional Courts, Baku, 4 September 2004), online: <http://www.venice. coe.int/webforms / documents/?pdf=CDL-JU (2004)047-e>.

${ }^{153}$ According to this provision, "[t]he Czech Republic shall observe its obligations under international law."

${ }^{154}$ Constitutional Court no II ÚS 604/o2 (26 February 2004).

155 Constitutional Court no I ÚS $310 / 05$ ( 15 November 2006). 
directly applied its provisions, for example, to deal with the issue of the state's responsibility for compensation of immaterial injury incurred as a result of the illegal deprivation of personal liberty, ${ }^{156}$ the issue of squeezeouts, ${ }^{157}$ or the long-term inactivity of Parliament in regard to the adoption of legislation regulating unilateral augmentation of rents and other matters related to rents. ${ }^{158}$ With respect to ordinary courts, it can be claimed that, in comparison with the 199 os when the Constitutional Court was, to a certain extent in relation to the ordinary courts, a pioneer in the application of constitutional norms, the situation has changed in that these courts also regularly refer to the provisions of the ECHR and use the European case law in their argumentation. ${ }^{159}$

Among the judgments of the ECtHR finding a violation of the ECHR which have had an impact on the amendment of the domestic legislation can be adduced, for example, the case of Rashed, ${ }^{160}$ which induced amendment of the Act on Asylum; ${ }^{161}$ the case of Macready, ${ }^{162}$ which brought about an amendment to the Act on Courts and Justices ${ }^{163}$ introducing a motion for the setting of time limits for procedural actions as a preventive measure against delays in judicial proceedings; or the case of Hartman, ${ }^{164}$ which induced in 2006 the adoption of a law providing for compensation for immaterial injury. ${ }^{165}$

In regard to the issue of the reopening of proceedings following judgments of the ECtHR that find a violation, a reopening of proceedings

${ }^{156}$ Constitutional Court no I ÚS 85/04 (13 July 2006).

157 Constitutional Court no III ÚS 2671/og (3 March 2011) or Constitutional Court no I ÚS 1768/og (21 March 2011). The Constitutional Court made reference to cases concerning the squeeze out dealt with by the ECtHR in the judgment of Kohlhofer and Minarik v Czech Republic, No 32921/o3 (15 October 2009).

${ }^{158}$ Constitutional Court no Pl ÚS 20/05 (28 February 2006). The Constitutional Court referred to art 1 of Protocol No I, supra note 151 .

${ }^{159}$ P Holländer, "The Role of the Constitutional Court in Application of the Constitution by the Ordinary Courts" in J Kranjc, ed, Law in Transition, Transition in Law (Ljubljana: Ljubljana Law Faculty, 2003) 89.

${ }_{160}$ Rashed v Czech Republic, No 298/o7 (27 November 2008).

161 Act No 325/I999 Coll on Asylum ("zákon č 325/I 999 Sb, o azylu a o změné zákona č 2 83/I 99 I Sb, o Policii České republiky, ve zněni pozdějších predpisů (zákon o azylu)").

162 Macready v Czech Republic, No 4824/o6 (22 April 2010).

163 Act No 6/2002 Coll on Courts and Justices ("zákon č 6/2002 Sb., o soudech, soudcích, přisedících a státni správě soudů a o změně některých dalšich zákonů (zákon o soudech a soudcích)").

${ }^{164}$ Hartman v Czech Republic, No 53341/99, [2003] VIII ECHR 317.

165 Act No I 60/2006 Coll, amending Act No 82/1998 Coll, on Liability for Damage Caused in the Exercise of Public Authority or by Improper Official Procedure ("zákon č I 6o/20o6 Sb., kterým se měni zákon č 82/I 998 Sb., o odpovédnosti za škodu způsobenou při výkonu veřejné moci rozhodnutím nebo nesprávným úředním postupem”). 
before the Constitutional Court is possible in both criminal and civil matters. Pursuant to Article 119 of the Act on the Constitutional Court, ${ }^{166}$ if the Constitutional Court renders a decision in a matter in which an international court later finds that a human right or fundamental freedom has been infringed contrary to an international treaty, a petition for reopening may be submitted against such a decision of the Constitutional Court, subject to conditions set down in that statute. The institution of the reopening of proceedings in criminal matters before the Constitutional Court was introduced in 2004 by an amendment to the Constitutional Court Act $t^{167}$ in reaction to the judgment of the ECtHR in the case of Krčmár and Others. ${ }^{168}$ As of 1 January 2013, it is also possible to reopen proceedings before the Constitutional Court in civil matters by virtue of an amendment to the Constitutional Court Act in 201 2. ${ }^{169}$

\section{CONCLUSION}

The dialogue between the national supreme courts and the ECtHR is conducive to the attainment of greater effectiveness in the protection of fundamental rights and freedoms by way of the harmonization of their interpretation and application. The interaction between the ECtHR and national courts is based on the principle of subsidiarity that allows national courts a wide margin of appreciation. The relationship between the ECtHR and national courts can be described as a balancing of power. Both the national and European courts have tools of their own enabling them to exercise their sphere of power vis-à-vis one another. While the ECtHR has the power to restrict the margin of appreciation of states by way of application of the European consensus doctrine or by specifying the measures that need to be adopted so that the legislation is rendered to conform with the ECHR, national courts dispose of great discretion with regard to the determination of the public interest justifying restrictions of the rights guaranteed by the ECHR. The use of European consensus in the legal reasoning of the ECtHR places restrictions not only on the margin of appreciation given to states but also on the ECtHR's evolutive interpretation of the convention. The fact that the ECtHR has interpreted the ECHR progressively in the light of the "living instrument" doctrine should not be

\footnotetext{
166 Act No I 82/I993 Coll, on the Constitutional Court ("zákon č I 82/I993 Sb, o Ústavním soudu").

167 Act No 83/2004 Coll, amending Act No I82/I993 Coll, on the Constitutional Court ("zákon č 83/2004 Sb, kterým se ménízákonč I 82/I 993 Sb, o Ústavním soudu, ve zněnípozdějších prèedpisü").

${ }^{168}$ Krčmár and Others v Czech Republic, No 35376/97 (3 March 2000).

169 Act No 404/2OI 2 Coll, amending Act No 99/I963 Coll, on the Code of Civil Procedure ("zákon, kterým se mèni zákon č 99/I963 Sb, občanský soudní rád, ve znění pozdějš́ch předpisů, a některé dalši zákony").
} 
perceived as the former having assumed the status of a supreme European human rights court. The principle of subsidiarity remains the major principle of interaction between the ECtHR and national courts, which was confirmed by the recent adoption of Protocol No. 15 to the ECHR.

The extent to which national constitutional courts implement the case law of the ECtHR varies depending on the status of the ECHR within the particular legal order, that order's system of constitutional protection of fundamental rights and freedoms, and the judges' will to apply the ECHR. Pursuant to national legal texts in both France and the Czech Republic, international human rights treaties enjoy supra-legislative force but are inferior to the Constitution. The Czech Constitutional Court, however, considers these treaties as forming part of the constitutional order and, therefore, treats them as being superior to ordinary laws. Due to the constitutional value of the ECHR accorded by the Czech Constitutional Court, the latter takes the convention as a norm of reference in judicial review of constitutionality and applies it directly in its decision-making, which means that it can strike down legislation and decisions of ordinary courts that are contrary to the convention. The implementation of the case law of the ECtHR in the Czech Republic, thus, is rather intensive.

However, this is not the case with the French Constitutional Council. Since it refuses to review laws for their compatibility with the ECHR, it seems not to be directly influenced by the letter of and practice under the convention. This situation may give rise to potential conflicts with the ECtHR. The French Constitutional Council has not accorded, unlike the Czech Constitutional Court, constitutional status to the ECHR. The resulting duality of review, for both constitutionality and conformity with the ECHR, and the fact that the Constitutional Council does not exercise the power to strike down laws that are in conflict with the ECHR, whereby it could eliminate, as well as prevent, possible interferences with the convention, runs the risk of potential clashes between the findings of the Constitutional Council, on the one hand, and those of the ECtHR and the French ordinary courts that review for compatibility with the convention, on the other hand.

These potential clashes involve situations where the Constitutional Council rules on the compatibility of national law with the Constitution, and the ECtHR finds that the same national law violates the ECHR, as well as situations where findings on the constitutionality and compatibility of laws with the convention do not coincide, and legislation that contravenes the ECHR remains part of the legal order. A recent constitutional reform introducing the mechanism of a priority question of constitutionality does not clear away this potential for conflict. Potential differences in the assessment of constitutionality and conformity of laws with the ECHR seem to be a point of friction in the relationship between the courts that review for conformity with the ECHR and the Constitutional Council, and a finding 
of a violation of the ECHR by the ECtHR may potentially lead an ordinary judge to interfere with the authority of the Constitutional Council.

There seems to be a dialogue, however, between the ECtHR and the French supreme courts reviewing for conformity with the ECHR, which performs the task of harmonizing national law with the convention and the case law of the ECtHR. Moreover, as a consequence of the introduction of the priority question of constitutionality, these courts have become de facto and de jure constitutional judges. The ECtHR undoubtedly has helped to improve human rights guarantees through domestic case law. In this regard, it can be said that there has been a Europeanization of protection as the law of the ECHR is integrated in the decision-making of French courts, including the Constitutional Council, and their Czech counterparts. But it is obvious that the effectiveness of the implementation of the norms and the case law of the ECHR at the national level would be enhanced if the convention were incorporated into the constitutional norms and principles that are taken into consideration in the framework of constitutional review of laws by the French Constitutional Council (bloc of constitutionality) and, thereby, obtained constitutional force. Constitutional review and the role of the French Constitutional Council, thus, would be reinforced to the level of the Czech Constitutional Court. 